\title{
Energy Needs and Efficiency, Not Emissions: Re-framing the Climate Change Narrative
}

\section{Nancy Birdsall and Arvind Subramanian (with Dan Hammer and Kevin Ummel)}

\begin{abstract}
The basic narrative on climate change between the rich and poor worlds has been problematic. The focus on emissions has made industrial countries inadequately sensitive to the unmet energy needs in developing countries. And it has led developing countries to adopt the rhetoric of recrimination and focus on the legacy of historical emissions by industrial countries. The ensuing blame game has led to the current gridlock. As a way out, we suggest some simple principles for determining equitable distribution of emission cuts between developed and developing countries to meet global targets. These principles emphasize basic energy needs and the equality of access to energy opportunities rather than emissions, taking account of development levels, as well as energy efficiency in creating such opportunities. To apply these principles, we develop a new data set to distinguish between energy needs and emissions-intensity for major developing- and developed-country emitters and quantify the relationship between these variables and changes in income (or development). This quantification allows us to project emissions levels in 2050. Our main finding is that meeting global emissions targets equitably requires very large, probably revolutionary, improvements in the carbon intensity of production and consumption, much larger than seen historically. We conclude that a new shared narrative that places equality of energy opportunities at the forefront would naturally shift the focus of international cooperation from allocating emissions "rights" or reductions and blame to maximizing efforts to achieving technology gains and rapidly transferring them worldwide. Abandoning the setting of emissions targets for developing counries and creating instead a framework where all countries contribute to maximizing technology creation and diffusion is what Copenhagen should be about.
\end{abstract}
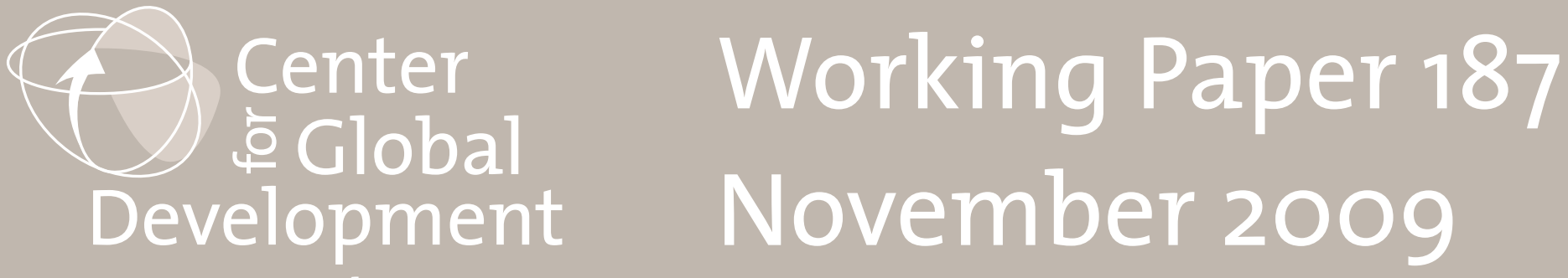


\title{
Energy Needs and Efficiency, Not Emissions: Re-framing the Climate Change Narrative
}

\author{
Nancy Birdsall \\ Arvind Subramanian \\ (with Dan Hammer and Kevin Ummel) \\ Center for Global Development
}

Nancy Birdsall is the President of the Center for Global Development in Washington, D.C. Arvind Subramanian is a senior fellow at the Center for Global Development and the Peterson Institute for International Economics, and a Senior Research Professor at Johns Hopkins University. For helpful discussions and comments on an earlier version of this paper, we are grateful to Liaquat Ahamed, Daniella Araújo, Pranab Bardhan, Barbara Bramble, Michael Clemens, Bill Cline, Nitin Desai, Andrew Deutz, Vera Eidelman, Kim Elliott, Jeffrey Frankel, Alan Gelb, Vijay Joshi, Devesh Kapur, Vijay Kelkar, Lee Lane, Aaditya Mattoo, Pratap Mehta, Darius Nassiry, Mead Over, Vijaya Ramachandran, Jairam Ramesh, Dani Rodrik, Liliana RojasSuarez, David Roodman, V. S. Senthil, John Simon, Christie Ulman, David Wheeler, John Williamson, and participants at the Conference on Climate Change Options for India held in New Delhi, 2009 and at the seminar at the Center For Global Development.

This paper was made possible by financial support from the UK Department for International Development.

Nancy Birdsall and Arvind Subramanian. 2009. "Energy Needs and Efficiency, not Emissions: Re-framing the Climate Change Narrative." CGD Working Paper 187. Washington, D.C.: Center for Global Development. http://www.cgdev.org/content/publications/detail/1423191

Center for Global Development 1800 Massachusetts Ave., NW Washington, DC 20036

202.416 .4000

(f) 202.416 .4050

www.cgdev.org
The Center for Global Development is an independent, nonprofit policy research organization dedicated to reducing global poverty and inequality and to making globalization work for the poor. Use and dissemination of this Working Paper is encouraged; however, reproduced copies may not be used for commercial purposes. Further usage is permitted under the terms of the Creative Commons License.

The views expressed in this paper are those of the author and should not be attributed to the board of directors or funders of the Center for Global Development. 


\section{Introduction}

What constitutes equitable burden-sharing on actions to address climate change is of fundamental importance and at the heart of differences between the rich and poor countries. It is really a question less of economics than of ethics, politics, and history.

Two recent, and important and influential reports on this subject—Nick Stern's Richard Ely Lecture of 2008, and the UNDP's Human Development Report (2008)_advocated allocating the future burden of emission reductions according to the 80-20 formula: rich countries would reduce their total emissions by 80 percent by 2050 relative to 1990 levels and poor countries by 20 percent. The World Bank's latest World Development Report does not advocate this split explicitly but could be seen as providing tacit support for it.

But these cuts do not seem to be based on any fundamental principles. They seem rather to be a combination of practical arithmetic (that the current science suggests total emissions in 2050 will have to be at least 50 percent below what they were in 1990) and political realities (based on the sense that rich countries cannot sell cuts larger than 80 percent domestically) combined with a nod to equity (that on the whole it seems fair that emissions per capita in developed countries, now about 10 times greater than in developing countries, ought to be converging or close to it by 2050, which is what the $80: 20$ split delivers very broadly). ${ }^{1}$

Meanwhile the only agreed principle in the context of the formal negotiations of a global agreement is the idea of "common but differentiated" obligations. In the absence of a more fundamental agreed principle about what is fair, and thus of any kind of shared narrative about the nature of the challenge, the formal negotiations of a climate change agreement, including between large developing country emitters (China and India especially) and the developed countries (the United States especially) are heavily constrained by their respective domestic politics. In the United States the media focus on the fact that China's total emissions now exceed those of the U.S., reinforcing the view, including in the U.S. Congress, that the U.S. should not commit to any reductions in its own emissions without explicit commitments by China and other major developing country emitters to reductions as well - in a reprise of the view that led to the U.S. Senate's 1997 resolution opposing any treaty that like Kyoto did not include such commitments by developing countries. Meanwhile in China and India, domestic politics and the reality and the demands of their growing economies for energy to drive growth and development, lead to a focus on their far lower per capita emissions.

Economists and other social analysts have not contributed effectively to resolving the tension between developed and developing countries around the question of burden-sharing - beyond defining the general principles of efficiency and equity as the basis for any agreement - and accepting the logic of "common but differentiated" obligations. Like Stern and UNDP, other authors (Frankel, 2009; Jacoby et. al., 2008) have tended to discuss the issue in terms of allocating the future "rights" to emissions across countries -- based on such parameters or combinations of them as current total emissions, cumulative past emissions, emissions per capita, per capita income and so forth.

\footnotetext{
${ }^{1}$ In Stern (2008), the arithmetic is that by 2050, total emissions should be down to about 20 gtons of GHGs, which should be divided equally between the world's population (about 9 billion in 2050) on the basis of some loose notion that every citizen has an equal right to pollute the global sink, an equal right to emissions.
} 
Not only are these proposals mostly arbitrary on burden-sharing. They are framed in our view from the wrong starting point, i.e. starting from the assumption that what is fundamental is the right to pollute or the right to the atmosphere in its capacity as a global sink. This starting point, has afflicted the basic conversation on climate change between rich and poor worlds — what one might call the narrative-in a way that has led to misunderstanding and recrimination and hence to limited progress in climate change discussions.

To move beyond this narrative, we propose a different perspective to an equitable distribution of burden sharing grounded in three principles.

1. Energy not emissions: First, and foremost, we posit that from an ethical perspective, what is primary is not the "right" to pollute, but access of people as consumers, independent of where they live, to basic energy-based amenities - such as meal preparation at home, pleasant ambient temperatures indoors, and or access to transportation ensuring personal mobility, at reasonable cost. The conflation of emissions and energy use is not surprising, since the production of energy to provide these services has historically been carbon-intensive. But as we show the link varies across countries and time. ${ }^{2}$ Equity in, or comparability of, access to energy-based services should be the touchstone, not emissions. Of course, the extent of pollution will have to observe the critical constraint of not heating the planet beyond what are now considered critical tipping points but that is a constraint not the primary objective.

2. History as guide to equitable energy access: Our second key point is that the right to energy services should be determined by a simple historical rule: developing countries' peoples' future access to energy services per se (not to emissions) should be no different from the energy services enjoyed by rich countries' peoples at the latter's comparable stages of development. Put differently, it would seem unfair for people in developing countries to be deprived of such access merely because they are late-comers to the development process-- late-comers, in the sense of others already having used up a key resource for development. To give a simple example, the access of a household in Chennai (India) to the services provided by air-conditioning or by cooking gas should be no different from its counterpart in Austin (United States) at comparable levels of income per capita. ${ }^{3}$

3. Future as basis for carbon efficiency: Lest this sound like a recipe for blowing up the planet, we add a third key point. While developing country people's access to energy services should not be compromised, the manner in which these services are met, or the efficiency of meeting given energy services, need not follow the same history-based trajectory as followed in the past in the advanced countries. For developing countries, the efficiency of meeting energy needs should reflect the most efficient technology actually available to them now and in the future, not the

\footnotetext{
${ }^{2}$ Our analysis below allows for the possibility of substitution across different forms of energy (as an input) - e.g. out of coal into hydro, nuclear and renewables - as a key mechanism for reducing the emissions-intensity of energy use (that is, as an output); indeed this may be the solution more easily affected by policy than any solution requiring reduced use of energy services (the output).

${ }^{3}$ One problem with this principle is it implicitly advocates replicating the historical errors made by rich countries in an era of low carbon prices. For example, cheap energy may have facilitated spatial location of production and consumption (migration from New England to Texas may have become feasible because of cheap air conditioning). As we note below, going forward developing countries in their own interests will want to avoid the public policies and practices that created incentives that led to these errors.
} 
technology used by advanced countries at comparable stages of development. To go back to the example, the technology used by the household in Chennai in getting the air-conditioning services in 2025 should not be the same as that used by the Austin household in 1990 (when say it had the same income level); instead, it should reflect and be very similar to the technology used by the Austin household in 2025 itself.

Making energy rather than emissions the touchstone brings the development dimension back into the climate change conversation in a way that was envisaged in the 1992 Rio declaration. It also has the advantage of avoiding a number of problems that an emissions-based approach has created. How so?

On the industrial country side, the focus on total emissions, while understandable given its close connections with the climate change problem, reflects an inadequate sensitivity to the unmet energy needs in developing countries, and the vast current inequities in energy access. That industrial countries can still contemplate trade sanctions against countries that consume one-fifth as much energy per capita as they do is one manifestation of the gulf that needs to be bridged.

A focus on emissions per capita while more equitable than that on total emissions is also problematic. The Stern Review and the Indian Prime Minister have conferred a special status on convergence in emissions per capita as a steady state objective. But as we show below disparities in energy use are even greater than those in emissions per capita. Consider the following example. Suppose the US and India achieved equality of emissions per capita in 2050. Suppose too that the US did so with a combination of very high energy use (consumption profligacy) and carbon efficiency. And suppose that India achieved it through a combination of very low energy use and carbon inefficiency. This would not be a fair outcome. Only if and when income per capita (and thus energy use per capita) and technology converge in the steady state can we expect convergence in emissions per capita. Until those two conditions are satisfied (well after 2050 by any reasonable assumptions), energy use and technology will merit separate attention; focusing on a combination of the two (i.e., emissions) could perpetuate inequitable development outcomes as the example illustrates.

The focus on emissions by developing countries has also created problems. They have insisted, with some justification, that the rich are responsible for past emissions and hence should pay "reparations" (a position espoused for example by Bhagwati (2006) in calling for the creation of a financial pool based on the experience of the Superfund clean-up in the United States); the rich retort by asking poor countries to take on the responsibility of having much larger populations and to recognize the contribution of the rich to the stock of new technologies and other global public goods. Regardless of the merits of these arguments, the blame game-a consequence of the prevailing narrative-has resulted in a level of mistrust that (as we write in late 2009) is undermining the negotiating process and slowing progress on a climate change accord. $^{4}$

The structure of the paper is as follows. Following a description of basic approach and data (Section II), we quantify the historical relationships between development on the one hand and energy consumption per capita,CO2 efficiency in production, and CO2 efficiency in

\footnotetext{
${ }^{4}$ While a focus on energy and efficiency rather than emissions might help the debate on climate change mitigation, whether this would carry over to the adaptation debate is less clear.
} 
consumption, on the other, using data covering developed and developing countries for the period 1994-2005 (Section III). We discuss briefly the resulting “development elasticities”, focusing in particular on the broad differences between developed and developing countries and the trends within the two groups.

In Section IV, we use our development elasticities along with assumptions about economic and population growth as the basis for projecting CO2 emissions in 2050 under a baseline or business as usual scenario, and then under two additional scenarios, based on different values for the development elasticities. ${ }^{5}$ In doing so we take into account two constraints (that reflect our second principle): developing countries should not face limits on per capita income growth (i.e. development) as a result of global efforts to reduce emissions; and developing countries' access to direct energy-related services should not be compromised. In a final section (V) we discuss the implications of our analysis and conclude.

As implied above, our more fundamental objective is to reframe the implicit "narrative" that has affected the negotiating positions of the major emitters, especially the United States in the developed world and China and India in the developing world. We believe our analysis provides the foundation for a less contentious and more productive negotiation and for recognition of common ground built on a common interest in maximizing the technological options and rapid diffusion of those options at reasonable cost. We return to this issue in our concluding section.

\section{Section II. Model and Basic Data}

We begin by noting that overall emissions stem from consumption of direct energy-related services and from emissions related to production and that these two need to be looked at separately. (Throughout we use “emissions” to refer to CO2 emissions.)

Total emissions, excluding from deforestation (which we ignore for lack of good data for many countries, particularly in the past) can be expressed as:

Total emissions = emissions associated with production activity ("production emissions") + emissions associated with "consumption of direct energy-related services" -- hereafter CDERS or "seeders")

Production emissions in turn can be expressed as:

Production emissions $=($ Emissions in production activity per unit of GDP $) *(G D P)$

Consumption emissions can be disaggregated as:

\footnotetext{
${ }^{5}$ We recognize that meeting global targets involves complicated CO2 dynamics in which the path of emissions beginning in 2020 is important. We focus on 2050 for analytical tractability but mainly because it helps to highlight the issues for Copenhagen more clearly. But our framework can easily be adapted to project the entire path of emissions from 2020.
} 
Consumption emissions per capita $=$ CDERsper capita $*$ emissions per unit of energy consumed

Thus the three variables of interest are:

(i) Direct energy-related services or CDERsper capita - the variable most closely corresponding to our equity principle;

(ii) Emissions from consumption per unit of energy consumed or simply the carbonintensity of energy consumption;

(iii) Emissions in production per unit of GDP, or the carbon intensity of energy production. ${ }^{6}$

The aim is to disentangle inefficiency of $\mathrm{CO}_{2}$ emissions generation (in production and consumption) from the consumption of direct energy-related services, our equity variable. ${ }^{7}$

\section{Data}

For a number of major GHG-emitting countries, we are able to calculate estimated household- or consumption-based emissions using data available from the International Energy Agency (IEA) on fossil fuel CO2 emissions across countries and over time, including from residential electricity use and vehicle use. To distinguish household transportation services from productionbased transportation we used data from the International Road Federation (IRF) and United States Transportation Bureau to estimate the share of road transportation emissions associated with personal automobile use, including the extensive use of light trucks and sport utility vehicles. (Appendix 1 provides more detail.)

Our production emissions variable is simply total emissions minus consumption emissions, so that we are including energy transformation emissions in production emissions (see Appendix 1). Actual production-based emissions include emissions from commercial, industrial, agricultural, and production-based transportation activities (Appendix Table 1) plus those produced in the transformation of energy, primarily to produce electricity.

For our key variable of interest, CDERs by consumers, we want to capture the consumption of energy-based services (and the resulting welfare gain for individual consumers). The CO2 data for CDERS relate to personal vehicle use and household electricity use; we would ideally have a measure of the outputs of services associated with these aspects of consumption. That is, for personal vehicle use, we would have a measure of distance travelled, and for electricity use, a measure of energy consumption such as kilowatt hours. We have some data on vehicle miles driven, but only for some countries for some years, and the data on kilowatt hours of electricity consumed are even more limited. We therefore had to opt for input-based rather than outputbased measures of energy services. Our variable representing CDERs is therefore the energy (measured in kilotons of oil equivalent -KTOEs) that goes into the "production" of road travel

\footnotetext{
${ }^{6}$ Thus, increases in the carbon intensity in consumption and production signal greater inefficiency.

${ }^{7}$ It is worth noting that many analyses of climate change (UNDP, 2008; World Bank, 2010) compute energy intensities of an economy by dividing total emissions by GDP. It is important to disaggregate as we have done to distinguish behavioral parameters (energy use) from technology parameters (carbon intensities in production and consumption).
} 
and electricity generation; the KTOE data were obtained from IEA and IRF data. ${ }^{8}$ In short, our CDER variable is not a pure measure of "energy services" but includes a substantial component of "energy" relative to the actual service that generates a welfare gain at the individual level.

Table 1 presents some basic energy use and emissions data for 2005 disaggregated along the lines shown in equations 1-3. For all countries, emissions from production still accounts for the bulk of total emissions. However, the share of emissions related to consumption is substantially greater for industrial countries (about 42-43\%) for the US, France and the UK) compared with India (22\%) and China (14\%).

The data show that industrial countries have indeed made a lot of progress in production efficiency - which can be seen in a decline in our measure, which is the $\mathrm{CO}_{2}$ emissions generated in production as a share of GDP (Figure 1 plots this ratio for some major emitters). ${ }^{9}$ Currently, for example, India is about $4 \frac{1}{2}$ times more inefficient than the US in production and even more so compared to some European countries (Table 1, column 6). China is almost twice as inefficient as India. But viewed historically, countries such as India both in terms of the level and trajectory of $\mathrm{CO} 2$ emissions do not appear to be doing badly.

This inefficiency of India and China, however, is less pronounced on the consumption side (column 5). For every unit of consumption, India generates 2-3 times more CO2 emissions than do the industrial countries and China about 11/2-2 times more (Figure 2). Appendix Figure 1 (bottom right hand panel) shows the striking gains made by Brazil when it introduced its push for the use of ethanol in automobiles.

The greatest disparities, however, relate to CDERs, our basic measure of energy consumption per capita (column 5). The United States' per capita consumption of energy is about 9 times that of China and 18 times that of India. Even the less profligate European countries consume substantially greater amounts of energy per capita than China and India (Figure 3).

One advantage of disaggregating emissions as we have done is to isolate the policy or actionable elements. For example, in the popular debate, the contrast is made between the total emissions per capita of the US and Europe on the one hand and developing countries on the other (column 1). But this aggregate comparison is misleading. On the one hand, it obscures the high levels of inefficiency in developing countries today (although not necessarily from a historical perspective); on the other, it obscures the striking consumption profligacy of the industrial countries.

Figure 2 plots consumption energy use per capita by per capita income for selected rich and poor countries. ${ }^{10}$ Consumption of energy per capita appears to have been rising slowly, especially in the United States. It is also rising in Brazil, though from relatively low levels compared to the

\footnotetext{
${ }^{8}$ We tried to calculate a more direct measure of energy services consumed using data available for some countries on vehicle miles driven. See Appendix table 2 for evidence, consistent with our approach, of the direct relationship between miles driven and GDP per capita for OECD countries, 1994 - 2005. But for most developing countries -including China and India -- data on miles travelled were not sufficient to identify a robust correlation between CDERS and GDP per capita.

${ }^{9}$ Appendix Figures 1 and 2 plot the variables of interest for individual countries but disaggregated by sectorshousehold energy use and travel.

${ }^{10}$ We use country-specific weighted averages of transport and road emissions in Figures 2 and 3. See Appendix 1.
} 
United States and compared to lower-income China. The low emissions in Brazil may be the outcome of its reliance on ethanol as vehicle fuel. Figure 3 plots consumption intensity for selected countries. Consumption intensity has been rising in China, India, and Brazil.

Consumption emissions intensity has been rising with income in those countries, though it is still below levels in the U.S. and other rich countries, where it appears to have stabilized.

\section{History: Estimating the development elasticities}

Our key argument is that the right to CDERs in the future should: (i) stem from an energy rather than an emissions perspective; (ii) be determined by the simple historic principle that the CDER profile for developing countries should be no different than that for industrial countries; but (iii) that this principle need not, and even should not, apply as such to the efficiency of meeting those CDERs.

In order to project future emissions, applying these principles, we need to quantify the historic development trajectory of the rich countries on each of the three variables we have identified: CDERs, the carbon intensity of consumption, and the carbon intensity of production. That is, we want to understand the relationship between each of these variables and the past development trajectory of the rich countries and quantify them in so-called development elasticities.

To estimate these development elasticities, we run panel regressions using annual data for a set of 25 developed countries for the period 1994-2005. ${ }^{11}$ We use country fixed effects in all our specifications to control for special features of countries. ${ }^{12}$ We run two specifications: a linear one, relating the relevant variable to income per capita (measured in constant PPP terms), and a quadratic specification relating the variable to income and income-squared (all variables are measured in log terms).

In Table 2, we report the results of this estimation for the consumption of energy variable (CDERs per capita). The estimates in both specifications are correctly signed and statistically significant. The magnitudes also seem plausible: for example, in the linear specification we obtain a development elasticity of energy consumption of about 0.8 for rich countries. That is, for every 1 percent increase in income per capita, per capita energy consumption increases by 0.8 percent.

As noted before, our CDER measure is an input-based measure of energy. We cross-check our findings by running similar regressions for output-based measures relating to personal transport. These results are reported in Appendix Table 2. The development elasticity for the output measure is broadly similar to the input-based measure.

We ran similar regressions for a sample of 12 developing countries with reasonable data. The linear specification yielded a coefficient of the CDER elasticity of 0.96. This near-unitary

\footnotetext{
${ }^{11}$ The sample of rich and poor countries is reported in Appendix Table 5. The elasticities were calculated from OECD countries and a select group of non-OECD countries, and then applied to a much larger sample of rich and poor countries for overall emissions reductions.

${ }^{12}$ In other words, our elasticities are not biased by the fact that the US is a large country and say Denmark is small because in essence we are only exploiting the variation across time within a country not across countries. We did not use time effects because of their high collinearity with the per capita GDP term on the right hand side.
} 
elasticity of energy needs in developing countries seems plausible because energy needs are highly elastic at low levels of income. ${ }^{13}$

For the development elasticity of the carbon-intensity of production, we estimate similar pooled regressions. Our results are reported in Table 3. In both sets of countries, the elasticity of the carbon intensity of production is negative, implying that with income the carbon intensity of production declines. Moreover, this elasticity is more negative for the rich countries $(-0.9)$ compared to the poor (-0.55), suggesting again that the rich countries have made greater strides on CO2 efficiency in production. Moreover, in the quadratic specifications, we find evidence for an inverted $\mathrm{U}$ : that is, the development elasticity of carbon intensity increases (i.e. worsens) up to a certain threshold level of income (about US\$ 12,700) and then declines.

We repeat this exercise to estimate the development elasticity of the carbon intensity of consumption. Here we tried two different specifications: in the first we related the carbon intensity of consumption to income per capita; and in a second to income per capita and the carbon intensity of production. The rationale for including the latter is the hypothesis that there would be some spillover from efficiency gains in production to consumption. These results are reported in Table 4.

In these regressions, the quadratic specification for the developed countries (column 3) implies that efficiency increases (or intensity declines), but only until per capita income of about $\$ 40,000$, beyond which inefficiency sets in - possibly reflecting the increased carbon intensity of consumption in the United States and a few other developed countries during the early $21^{\text {st }}$ century boom; we do not believe that pattern of growing intensity/inefficiency is likely in the future. In the column 5 specification, the high correlation between income per capita and the carbon intensity of production leads to unstable estimates when both are included. Thus, our preferred specification is that in column one, in which the only right-hand side variable is income per capita. In this specification, the development elasticity of consumption inefficiency is -0.1 for rich and 0.1 for poor countries. These estimates are again plausible (see Appendix figures) insofar as they imply that the rich have made greater strides in improving the carbon efficiency of consumption than the poor; the positive elasticity for the latter suggests that they appear to be at a stage where income growth still leads to a high and rising carbon intensity of consumption.

Thus, our empirical analysis covering the period 1994-2005 clarifies that: (1) developing countries are still far more carbon-intensive in their production than are developed countries, but that in virtually all countries, the elasticity is negative, that is, the trend is in the direction of greater efficiency; (2) there are also efficiency gains in terms of emissions associated with consumption though they are more modest; in developed countries, the elasticity with respect to recent to income growth is negative but in developing countries it is positive (though low); (3) in marked contrast, energy use in both sets of countries is still rising almost as fast as income, particularly in developing countries. In developed countries, the elasticity is lower than in developing countries and (as the quadratic suggests) is trending down, perhaps because people are conserving with income growth, either using less energy directly (turning down the thermostat) or investing to insulate and using less energy for the same degree of warmth. ${ }^{14}$ The

\footnotetext{
${ }^{13}$ The quadratic specification for the poor countries did not seem plausible.

${ }^{14}$ We could distinguish between these two possibilities only if we had a measure of the energy service outcome ("warmth") but we have only a measure of the energy service input (household use of energy in ktoes).
} 
implication is not surprising; energy services are a normal good and we should expect demand for them to rise with income - and apparently somewhat faster at lower levels of income where "needs" have been less fully met.

\section{Projecting Emissions in 2050 under alternative scenarios}

Based on these development elasticities, we now project emissions in 2050 under alternative scenarios. The methodology for these projections is explained in detail in Appendix 2. ${ }^{15}$

\section{Business-as-usual (BAU) scenario}

We start first with the baseline or business-as-usual (BAU) scenario. While we have estimated historical development elasticities, it is possible that these will change over time. For example, the fact that the elasticity of production efficiency with respect to income has been declining in the past implies it will decline further over time, even in the business-as-usual scenario. We take this into account by estimating an elasticity for 2005 and for 2050. We then average these two to capture the behavior over the period as a whole (details are described in Appendix 2 and a summary of these elasticities is presented in table 5). We use this same procedure for projecting the carbon intensity of consumption.

For developing countries too, we need elasticities for 2005 and 2050. For the former, we use the historic development elasticities estimated from our regressions. For 2050, we assume that these elasticities will evolve not in a manner resembling their own past gains in efficiency but will also benefit from future technological improvements driven by “development” (income growth) in the developed countries; as developing countries close the income gap with developed countries, there will be some flow of these new technologies from rich to poor. So this scenario reflects the assumption that the efficiency parameters for the poor will converge toward the rich country parameters by a factor depending on how much of the income gap between rich and poor is narrowed.

For the CDERs, which are demand-based and meant to reflect need rather than being linked to technology, we assume that poor countries will behave in the future like the rich countries have behaved at a comparable stage in their development in the past. ${ }^{16}$ This reflects our second principle that energy services should be related to income levels - which as our empirical results told us for the recent past, implies increases in demand and use that are close to pari passu with increases in income per capita.

Table 5 shows the resulting calculated elasticities for 2005 and for 2050. The alpha parameters refer to the development elasticity of the carbon intensity of production emissions, the gamma parameters to the development elasticity of the carbon intensity of consumption emissions, and the beta parameters to the development elasticity of energy use per capita.

\footnotetext{
${ }^{15}$ We should note an important caveat here. Clearly, emissions reductions efforts will themselves have a feedback effect on growth which we do not incorporate. More broadly, capturing many of these effects will require a fullyspecified dynamic model which is beyond the scope of this paper. Our aim is to highlight some broad principles and effects rather than identify precisely the relevant magnitudes.

${ }^{16}$ Technically, this means that we use the rich country beta parameter for the poor countries, calibrated for the level of development.
} 
One point that we want to highlight is the distinction between principles two and three. In principle two, we argue that history can be a guide in determining energy access. But principle three embodies the notion that the future not history should be the basis for carbon efficiency. To illustrate this distinction, we draw attention to the alpha and beta parameters in Table 5. For developing countries, we assume that the future beta parameter (which reflects consumption of energy services) will be the same as the industrial country value when the latter attained the income level that developing countries will in the future. In contrast, for developing countries, we do not assume that the future alpha parameter (which captures carbon efficiency in production) will be the same as the industrial country value when the latter attained the income level that developing countries will in the future. Had we done so, the value of the alpha parameter would have been -1.06. Instead, we assume a value of -1.63 , a considerably higher level of efficiency, because we into account gains in carbon efficiency that will occur in the future.

Based on these assumptions, in the BAU scenario, we find that rich countries' emissions will increase by about 50 percent and poor country emissions by about 190 percent from the 1990 baseline year.

In this scenario, we can back out what might be called a notional or a benchmark equitable burden sharing rule for rich and poor countries. This is done by asking what percentage emissions reduction would have to be implemented in the rich countries given the BAU emissions profile for poor countries and given the scientifically determined constraint that global emissions will have to decline by 50 percent relative to 1990 levels to prevent environmental catastrophe. This serves as a benchmark because it identifies clearly how much rich countries would have to do (or undo) to ensure that the development potential of poor countries is not compromised or constrained because of past actions of the rich countries - in the absence of technological or behavioral changes beyond those associated with increasing income per capita (or "development"). In some respects this is similar to the argument of those who call for all the incremental burden of reductions to be borne by the rich countries, and to those who argue for future emission rights to be based inversely on cumulative past emissions. But our derivation is different because it is based not on emissions per se but on the objective of energy needs and development and is clearly related to the principle of historic comparability that we have advanced.

Equitable burden sharing in the business-as-usual scenario would involve rich countries cutting their emissions by 251 percent; that is, for developing countries to continue on a relatively unconstrained development path, rich countries would have to find ways not just of going to zero emissions but actually contributing negative emissions (for example, through re-forestation that adds to the carbon absorption capacity of the atmosphere). While this may be unrealistic and even scientifically infeasible, it shows that the 80-20 emission reductions rule that is currently being discussed could in fact, in the absence of more rapid technological or other changes, constrain the development process in poor countries despite seeming to put the greater burden of future emissions reductions on the rich countries.

Under this equitable burden sharing rule (which is still very demanding because it assumes that developing countries will continue to make strides in carbon efficiency), China and India would increase their emissions relative to 1990 levels by about 172 percent and 349 percent, 
respectively. Their corresponding emissions per capita numbers would be 6.30 and $2.62 .{ }^{17}$ These are the relevant numbers that should inform the debate on equitable burden sharing and provide a contrast with current view that developing countries should cut their emissions by 20 percent.

\section{Current technology frontier scenario}

In our second scenario, we assume that for the period 2005-2050, all developed countries reach the frontier level of carbon efficiency in consumption and production and also reach the frontier level of restraint in energy consumption. These frontier levels are determined by running the three sets of regressions for each country, and identifying that country which has the best performance. For efficiency levels in consumption and production, Germany is the best performer (see Appendix Table 4); and Australia is the best performer on the energy use elasticity. For developing countries, we assume that the efficiency parameters follow the developed country efficiency parameters. That is, we apply the absolute difference between the efficiency parameters in Scenario 1 to the efficiency parameters in Scenario 2.

But we continue to assume that the direct consumption energy related needs of poor countries are as in the BAU scenario. In other words, we posit that equitable burden sharing involves no reduction in the energy needs of developing countries relative to the BAU scenario. This assumption is, of course, at the heart of our equity principle.

With these assumptions, total emissions still rise by nearly 47 percent in developing countries (while declining by 12 percent in the rich countries). Global emissions rise by 15 percent. In this scenario, with all countries reaching the current frontier, an equitable burden sharing rule would require the rich to decrease emissions by 132 percent.

\section{Avoiding Armaggedon scenario}

Neither of the scenarios described above comes close to meeting the target for reducing global emissions by 50 percent by 2050 - indeed they both imply emissions continuing to rise. In the final scenario, we ask what improvements in the efficiency parameters are necessary in rich countries which if also adjusted rapidly in developing countries would deliver the global emissions reductions target of 50 percent by 2050. To ensure a total reduction of 50 percent, we impose sufficient reduction of the alphas and gammas in the developed countries, while maintaining the absolute differences between them noted in Scenario 2 - in effect assuming massive improvements in technology in the developed countries and considerable catch-up in the developing countries via transfer of technology and their own technological breakthroughs. We continue to assume that poor countries' energy consumption services are not compromised in this scenario.

As Table 6 shows, very large improvements in the efficiency parameters in both developed and developing countries are necessary to meet the global target consistent with avoiding climate change Armaggedon. Compared to the business-as-usual scenario, our calculations imply that the elasticity of the carbon intensity of production in developed countries would have to improve

\footnotetext{
17 The 1990 level of total emissions for China was 2,243 MTCO2, whereas the projected level of total emissions in 2050 is 8,796 MTCO2, which represents a four-fold increase. Population is projected to increase by over 260 million at an average annual growth of $0.18 \%$, which yields the final value of 6.30 tCO2 per capita. Note that even after the tremendous growth in absolute emissions, emissions per capita is still far below that of the US today.
} 
(decline) by 2.5 percentage points, from -1.45 to -4.06 ; and the elasticity of the carbon intensity of consumption by 0.9 percentage points, from -.07 to -0.99 .

How big are these required changes? One way to assess whether such gains are possible is to ask whether similar gains have even been achieved in the past by the industrial countries. One natural experiment that we can exploit to shed light on this question is the oil price shock in the early 1970s, when energy prices increased four -fold. We estimated the development elasticities for the carbon intensity of production and for energy use for periods before and after that oil shock. The results are reported in Table 7 . We find that the production elasticity improved (i.e. declined) substantially from about -0.1 to -1.1 before and after the oil shock; for the energy use elasticity the improvement was far more modest, with a decrease from 1.25 to 1.16 between the two periods.

While these numbers are merely illustrative, they nevertheless confirm two findings of our analysis of development elasticities (in which we assessed the apparent effects of changes in per capita income as opposed to price changes ${ }^{18}$ ): (1) at least in the case of oil-based services, efficiency gains were far more responsive to the price increase than was demand for the service consistent with our approach of imposing in our scenarios far greater declines ("improvements") in the alphas and gammas than in the betas); and (2) even with the massive energy price changes in the early 1970s, the improvement in efficiency was far short of what will be required in the future if global emission targets are to be met.

Sensitivity analysis points to the same conclusion. We ask what the impact on emissions outcomes would be of changing the (alpha and gamma) efficiency parameters as opposed to the (beta) CDERs parameter. These map roughly into a comparison of the bang-for-the-buck from technology improvements versus conservation efforts. We find that for an equal percentage change in the two, the bigger impact on emissions is greater from changing the efficiency parameters in part because even going forward emissions in production will constitute the larger part of total emissions. Table 8 illustrates this.

A 25 percent improvement in the efficiency parameters reduces global emissions by a further 13 percent from 50 percent to 63 percent. In contrast, a 25 percent reduction in the energy use parameter reduces global emissions only by a further 6 percent. This has the implication that getting developing countries or for that matter developed country consumers to compromise on their energy needs may not necessarily be where the major policy effort should reside. It is perhaps far better to focus on technology improvements without which, in any case, there is no prospect for achieving the global emissions targets. Reducing the carbon-intensity of both production and consumption-based emissions rather than reducing consumption profligacy or consumption of energy services per se is where the big bang for the buck seems to reside.

\section{Discussion and key take-aways}

In a recent Financial Times-Harris poll, 60 percent of Americans thought that in any climate change agreement China should reduce emissions the most. And in the same poll, only 20 percent of respondents agreed that "since developing countries have not caused as much climate

\footnotetext{
${ }^{18}$ The development elasticities can be thought of as reduced forms in which per capita income changes reflect many other factors, including policy responses and price changes as well as changes in demand.
} 
change, developed countries should be prepared to give them more aid to deal with the consequences.”

Only a fundamental problem in the narrative on climate change can elicit such responses. The rich world has focused on greenhouse gas emissions. This has been unavoidable to some extent because the science, quite rightly, focuses on the "thing" that threatens the planet. But people, especially those in the poorer parts, don't consume emissions. They consume basic energy services. And the reality is that most of them do not have access to basic cooking, heating and transportation services. To them, being asked to cut emissions is like asking them to go from just emerging above bare subsistence to, literally, the dark and ice ages.

Developing countries themselves have not been blameless, and again the focus on emissions has played a role. They have succumbed to the rhetoric of recrimination. You the rich have created the global "bad" of polluting the atmosphere and you should therefore pay reparations going forward they say. But the rich retort by asking developing countries to take responsibility for their large populations and to take account of all the global "goods" they have created such as technology.

Rarely, in history, have we seen constructive solutions coming out of blame games such as this. In this paper we suggest a way out of the current impasse. Our contribution is threefold.

First, we posit some simple principles, focusing on energy needs (for consumers) and efficiency rather than emissions "rights," as the appropriate indicators on which to build a narrative on what is fair in a climate accord.

Our second contribution is methodological. We show that these principles can be quantified. To do so, we disaggregate existing data on emissions and energy production in a new way, enabling us to distinguish energy needs from the efficiency of energy use in production and consumption. This disaggregation allows us to quantify historical relationships between energy needs and the efficiency of energy use in production and consumption on the one hand, and development on the other. Our key result is that carbon efficiency gains have responded to "development" in the form of per capita income increases far more rapidly than has "conservation" in the use of energy services.

Our third contribution relates to the results of our projections exercise. We use our empirically grounded "development elasticities" as the basis for defining clearly specified alternative assumptions for how they could change - our scenarios. Along with country-specific information on likely growth of income and population we are able to quantify the magnitudes of likely and possible changes in emissions over the next four decades under our different assumptions. Our key finding is that improvements in technology at rates consistent with those we observed historically, even for the most carbon-efficient economies among major emitters, provide little hope of meeting the broadly agreed global target for emissions reductions of 50 percent relative to 1990 .

That implies that any prospect of meeting the aggregate global emissions target, consistent with developing countries not sacrificing their energy needs, will require massive, revolutionary, improvements in the technology margins (production and consumption) - far greater than seen 
historically. Only with these improvements and their worldwide diffusions would the current 80:20 emissions reductions distribution between rich and poor advocated by Lord Stern and the UNDP be equitable and hence politically acceptable. Otherwise this burden-sharing rule would almost surely be inequitable by our definition, since in developing countries managing even a 20 percent reduction in emissions would imply lower pure energy use for given income by their people than enjoyed by people in developed countries.

Our results also bear on the positions taken by the two major developing country players-China and India — on two key issues. First, our results suggest that the position advanced by the Indian Prime Minister - namely to seek equality of emissions per capita in the long run — should be reframed to set equality of access to energy services per capita as the appropriate long-run goal.

Second, our results underline the logic of the position of China in announcing domestic targets focused on carbon efficiency while rejecting international commitments to emissions mitigation. Lord Stern has argued that developing countries should conditionally commit to emissions targets, with the conditions relating to appropriate financial and technological transfers. We would argue that the conditional commitment might be not to emissions targets but to carbon efficiency targets - and only later, when technological gains are proven feasible and financial and technological transfers are operating so that low-carbon innovations are actually increasingly available, to commit to international targets.

Given the critical importance of achieving substantial technology gains, the world needs to go on war footing to meet this goal. Developing countries should themselves take the lead in initiating major international efforts on technology generation and dissemination. For example, they should negotiate massive support for public funding of green energy research, including by and in the rich countries, and for full access to new technologies, and they should consider making financial contributions commensurate with their size and financial ability to international funds for technology creation. In other words, developing countries' rightful calls for equity must be combined with leadership-financial, technological, and institutional-in the collective effort to save the planet.

At the international level, moreover, much more attention needs to be devoted to the international rules and arrangements for generating and diffusing clean technology, and thus to the appropriate property rights regime to minimize the tradeoff between incentives for innovation and the logic of maximum low-cost and rapid access. On this issue, both the United States, which has taken a traditional stance in defense of intellectual property rights to maximize private investment and innovation, and China, which is focused on maximizing access, would ideally collaborate in design of an effective arrangement.

The United States and other developed countries should on their part abandon their call for immediate commitments from developing countries to reduce emissions, and focus instead on the nature of the bargain (between the public and private sectors as much or more than across countries) for maximizing technology creation and diffusion. They should welcome advanced developing countries' programs focused on reducing the carbon-intensity of their production as rapidly as possible and focus on international verification of those gains as a basis for enhancing cooperation on financial, and especially, technology transfers for mitigation. 
Finally, our most fundamental point bears emphasis: if all countries could converge around a new shared narrative that places equality of energy opportunities at the forefront, this would naturally shift the focus of international cooperation from emissions and blame to maximizing efforts to achieving technology gains and rapidly transferring them worldwide. 


\section{Appendix 1: Data Description and Parameter Estimation}

The International Energy Agency provides detailed data on flows of energy-related carbon dioxide emissions and energy supply, conversion, and consumption, broken down by fuel type and sector. This information is sufficient to break total final consumption into "consumption" and "production" activities as reported in the Data section. The categories used in the IEA data are similar to those presented in Appendix Table 1.

Estimated emissions are provided for direct fuel combustion in each end-use sector. To this we add emissions resulting from electricity use in each sector. This is calculated by estimating the amount of carbon emitted by the domestic power sector for each unit of electricity and heat delivered to end users and multiplying by reported electricity and heat use.

The IEA data includes a single end-use sector for road transportation emissions, which we must further decompose into consumption and production components. We take the consumption component as total emissions resulting from use of passenger cars. Data from the International Road Federation provide estimated miles traveled by passenger cars, trucks, and motorcycles by country-year. In the single case of the United States, we use vehicle census data from the Bureau of Transportation to add in miles traveled by sport utility vehicles and pickup trucks that are employed in personal use.

To estimate emissions precisely, one would need the ratios of average fuel economy between passenger cars, trucks, and motorcycles for each country-year. Since this data does not exist, we simply assume these ratios based on data from the US Bureau of Transportation. For non-US countries, we assume that average emissions per mile traveled for the "truck" fleet (which includes large trailers) is $76 \%$ greater than that of passenger cars. Motorcycles emissions per mile traveled are assumed to be about $40 \%$ that of passenger cars. For the US, these figures are $61 \%$ and $44 \%$, respectively, reflecting the different composition of the "truck" and passenger car” categories in the US (the latter including SUV's and pickup trucks).

These ratios are applied to estimated miles traveled and the resulting values applied to total road emissions from the IEA data to estimate total emissions for each category (trucks, passenger cars, and motorcycles). Passenger cars and motorcycles are added together and constitute consumption-related transportation emissions. Truck emissions are added to non-road emissions (railroads, boats, etc.) and constitute production-related emissions.

For country-years where there is insufficient data to make a direct calculation, an estimate is developed using a linear regression where the consumption-related share of total transportation emissions is the dependent variables and log of per capita GDP, the share of agriculture in GDP, the urban share of population and the urban share of population squared are the dependent variables, including region fixed-effects. The regression results (below) are used to fit a predicted value. This value is then used to linearly interpolate missing values in each country's time series. The resulting value (estimated consumption-related share) is multiplied by total transportation emissions in the IEA data.

Consumption-related emissions include those resulting from energy use in the residential sector and "passenger cars.” Production-related emissions are technically total energy-related emissions 
minus consumption-related emissions. In effect, this residual includes emissions resulting from commercial and public services, industry, agriculture (not including emissions from deforestation), and the "truck" and non-road components of transportation.

Production and consumption emissions in 2005 are compiled for each country listed in Appendix Table 4. Then, for the select countries listed in Appendix Table 5, emissions and supplied household energy are compiled for each year in the period 1994-2005. From this data, we estimate the elasticities discussed in the text, and then apply the parameters to the emissionlevels for all countries in 2005 -- projecting forward to 2050.

In Scenario I, we estimate business as usual, whereby we aggregate all country-years for the two groups -- developed and developing -- and estimate the parameters from pooled regressions, with fixed effects. The results of these regressions are presented in Tables 3-5 in the text. In Scenario II, we consider the development elasticities of individual countries. The parameter estimates for individual countries are provided in Appendix Table 3. 


\section{Appendix 2: Projecting Emissions in 2050 in the Business-As-Usual Scenario}

In order to project global emissions in 2050, we divide total emissions (TE) into two, disjoint categories, namely production emissions (PE) and consumption emissions (CE), and we further disaggregate them as shown in equations 1-3 in the text. This disaggregation yields three variables of interest: energy use per capita; carbon intensity in production; and carbon intensity in consumption. We project total emissions by projecting each category separately, based on how consumption and production emissions have historically moved with population and GDP in both low and high income countries. That is, we collect various elasticities of carbon emissions and intensities with respect to GDP for use in projecting emissions forward.

For production emissions, we estimate the elasticity of production carbon intensity (tCO2/\$1000GDP) with respect to GDP per capita in PPP. The parameter of interest is given by $\alpha_{1}$ in the following regression:

$$
\log \left(x_{i t}\right)=\alpha_{0}+\alpha_{1} \log \left(q_{i t}\right)+\varepsilon_{i t},
$$

where $x_{i t}$ is the ratio of production emissions to GDP (in constant dollars) for country $i$ in year $t$, and $q_{i t}$ is GDP per capita in PPP. The estimating equation includes country fixed effects which we do not show for presentational simplicity. The parameter is estimated for all high income countries for the period 1995 to 2005, and separately for all low income countries for the period 1995 to 2005 . $^{19}$

For consumption emissions, the specification is slightly more complicated, since we are interested in more than one intensity measure on the consumption side. First, we collect the elasticity of consumption energy use (ktoe/person) with respect to GDP per capita, or $\beta_{1}$ in the following equation:

$$
\log \left(y_{i t}\right)=\beta_{0}+\beta_{1} \log \left(q_{i t}\right)+\varepsilon_{i t}
$$

where $y_{i t}$ is consumption energy per person for country $i$ in year $t$, and $q_{i t}$ is GDP per capita in PPP. (Again country fixed effects are not shown). The measure of consumption energy is effectively proxied by the amount of supplied residential energy (in ktoe), summed with the amount of energy supplied to personal automobiles (in ktoe). Total consumption energy for each country-year will be denoted by $\omega_{i t}$ for future referenced. The split between consumption and production emissions from road travel is approximated by combining IEA and IRF data.

Second, we collect the elasticity of consumption emission intensity (tCO2/ktoe) to GDP per capita, represented by $\gamma_{1}$ :

$$
\log \left(z_{i t}\right)=\gamma_{0}+\gamma_{1} \log \left(q_{i t}\right)+\varepsilon_{i t}
$$

where $z_{i t}$ is the ratio of consumption emissions to consumption energy.

\footnotetext{
${ }^{19}$ High and low income countries are determined by the World Bank classification. Roughly, we define developing countries as low- and middle-income countries, according to the 2008 WDI. Developed countries are high-income countries, both OECD and non-OECD. We reclassify some countries, like Russia. An exact list of "developed" and "developing” countries is provided in the Appendix Table 5.
} 
Thus, on the consumption side, profligacy is approximated by $\beta_{1}$ and efficiency (or rather inefficiency) is approximated by $\gamma_{1}$. Note that the alphas and gammas capture technology parameters while the beta is a behavioral parameter.

The estimated parameters describe the historical behavior of how carbon emissions and energy use have changed with GDP and population. We use these parameters as the basis for our projections, with slight modifications or transformations to account for changing conditions and data quality. Suppose, for now, that we insert directly the average elasticities estimated in equations (1), (2), and (3) as the provisional parameters into the "projection equations" below.

$$
\begin{aligned}
& P E_{50 i}=\exp \left[\alpha_{1}\left(\log \left(q_{50 i}\right)-\log \left(q_{05 i}\right)\right)+\log \left(x_{05 i}\right)+\log \left(Q_{50 i}\right)\right] \\
& \omega_{50 i}=\exp \left[\beta_{1}\left(\log \left(q_{50 i}\right)-\log \left(q_{05 i}\right)\right)+\log \left(y_{05 i}\right)+\log \left(P_{50 i}\right)\right] \\
& C E_{50 i}=\exp \left[\gamma_{1}\left(\log \left(q_{50 i}\right)-\log \left(q_{05 i}\right)\right)+\log \left(z_{05 i}\right)+\log \left(\omega_{50 i}\right)\right]
\end{aligned}
$$

where the subscript indicates the year (2005 or 2050) and country, $Q_{50 i}$ is the projected GDP in constant dollars in 2050 for country $i$, and $P_{50 i}$ is the projected population in 2050 for country $i$. The GDP and population projections are extracted from the ERS International Macroeconomic Data Set, via the USDA. The projection equations, then, relate future emissions and energy use to our parameter estimates $\left\{\alpha_{1}, \beta_{1}, \gamma_{1}\right\}$ and secondary projections. Note that equations (5) and (6) can be further compacted, so that:

$$
C E_{50}=\exp \left[\left(\beta_{1}+\gamma_{1}\right)\left(\log \left(q_{50 i}\right)-\log \left(q_{05 i}\right)\right)+\log \left(C E_{05 i} / P_{05 i}\right)+\log \left(P_{50 i}\right)\right]
$$

The estimated elasticities from equations (1), (2), and (3) may not be the most appropriate to use in the projection equations. That is, the historical (linear) path of emissions and energy use may not reflect what we expect to happen in the future. We adjust the parameters accordingly. Essentially, we need a parameter that will reflect the experience for the period 2005-2050; roughly speaking we need the average elasticity between 2005 and 2050. For 2005, we use the estimated development elasticities. To obtain an estimated elasticity, we employ a quadratic model, so that the elasticity of, say, production intensity with respect to GDP per capita is allowed to vary with income. The respecified production intensity regression is:

$\log \left(x_{i t}\right)=\dot{\alpha}_{0}+\dot{\alpha}_{1} \log \left(q_{i t}\right)+\dot{\alpha}_{2} \log \left(q_{i t}\right)^{2}+\varepsilon_{i t}$

This quadratic yields an elasticity that is itself a function of income. We can substitutue for the value of income that we have projected for 2050 and obtain the relevant elasticity for 2050. Projection equation (4) is adjusted accordingly:

$$
P E_{50 i}=\exp \left[\left(\left(\dot{\alpha}_{05 i}+\dot{\alpha}_{50 i}\right) / 2\right)\left(\log \left(q_{50 i}\right)-\log \left(q_{05 i}\right)\right)+\log \left(x_{05 i}\right)+\log \left(Q_{50 i}\right)\right]
$$

Where $\dot{\alpha}_{05}$ and $\dot{\alpha}_{50}$ refer to the elasticities for the two periods, the average of which is then used in the projection. A similar adjustment can be made for the consumption emissions projection. This is the framework we use to adjust the parameters; although, the actual parameter specification is slightly more complicated and idiosyncratic. The precise specifications are articulated below. 
ALPHAS. For the rich countries for 2005, the precise elasticity is calculated from the estimated quadratic parameters (sample, 1994 - 2005), using average GDP per capita in 2005 for the Rich country sample. For the rich countries for 2050, the precise elasticity is calculated from the estimated quadratic parameters (sample, 1994 - 2005), using projected average GDP per capita in 2050 for the rich country sample.

For the poor 2005 countries for 2005, the elasticity is calculated from the estimated quadratic parameters (sample, 1994 - 2005), using average GDP per capita in 2005 for the poor country sample. For the poor countries for 2050, we use the idea that there will be convergence in the alphas (because this is broadly a technology parameter) matching the convergence in the incomes between rich and poor that we project. Specifically, for getting the 2050 elasticity for the poor countries, we calculate the ratio of rich to poor incomes in 2050 and 2005. We then take the ratio of the ratios: rich to poor income ratio in 2050 over rich to poor income ratio in 2005. This final ratio represents the income convergence over the 2005-2050 period, and is used to appropriately scale the difference between the rich and poor alphas in 2005 . The idea is that the difference between the alphas will converge over 2005-2050 in line with the convergence of incomes.

BETAS. For the rich countries for 2005, the precise elasticity is calculated from the estimated quadratic parameters (sample, 1994 - 2005), using average GDP per capita in 2005 for the Rich country sample. For the rich countries for 2050, the precise elasticity is calculated from the estimated quadratic parameters (sample, 1994 - 2005), using projected average GDP per capita in 2050 for the rich country sample. This follows the same procedure that we used for the alphas.

For the poor countries for 2005, the elasticity is calculated from the estimated quadratic parameters (sample, 1994 - 2005), using average GDP per capita in 2005 for the poor country sample just as we did for the alphas. For the poor countries for 2050, the elasticity is calculated from the estimated quadratic parameters (sample, 1994 - 2005, but sample for the rich countries), using average GDP per capita in 2005 for the poor country sample. The reason we use the estimated elasticity from the rich country sample is based on the hypothesis that when the currently poor attain the incomes of today's rich, their energy needs will be similar. Note that this would not be valid where we are estimating technology parameters but may be more defensible where we estimated behavioral parameters.

GAMMAS. For the rich countries for 2005, the precise elasticity is calculated from the estimated quadratic parameters (sample, 1994 - 2005), using average GDP per capita in 2005 for the Rich country sample. For the rich countries for 2050, the precise elasticity is calculated by multiplying the 2005 Rich gamma by the ratio of 2050 Rich alpha over 2005 Rich alpha. The rationale is that gamma, which is really a technology parameter, will mimic the evolution of alpha, which is also a technology parameter.

For the poor countries for 2005, the elasticity is calculated from the estimated quadratic parameters (sample, 1994 - 2005), using average GDP per capita in 2005 for the poor country sample. For the poor countries for 2050, the gamma parameter is calculated in exactly the same way as the alpha parameter for the poor countries in 2050. That is, it is the scaled difference between the rich and poor gamma parameters in 2005, to reflect the convergence in incomes. 
TABLE 1: Selected Indicators (2005)

\begin{tabular}{|c|c|c|c|c|c|c|}
\hline & $\begin{array}{l}\text { Total } \\
\text { Emissions }\end{array}$ & $\begin{array}{l}\text { Emissions per } \\
\text { capita }\end{array}$ & $\begin{array}{l}\text { Share of } \\
\text { Consumption } \\
\text { Emissions in Total } \\
\text { Emissions }\end{array}$ & $\begin{array}{l}\text { Consumption } \\
\text { Energy Use per } \\
\text { capita }\end{array}$ & $\begin{array}{l}\text { Carbon } \\
\text { Intensity of } \\
\text { Consumption }\end{array}$ & $\begin{array}{l}\text { Carbon } \\
\text { Intensity of } \\
\text { Production }\end{array}$ \\
\hline Country/unit & MTCO2 & $\begin{array}{r}\text { tCO2 per } \\
\text { person } \\
\end{array}$ & in percent & $\begin{array}{l}\text { tons of oil equiv. } \\
\text { (TOE) per person }\end{array}$ & tCO2/TOE & MTCO2/\$1000 \\
\hline Bangladesh & 36 & 0.24 & 0.36 & 0.09 & 7.48 & 0.38 \\
\hline Denmark & 48 & 8.77 & 0.33 & 1.38 & 6.07 & 0.19 \\
\hline Philippines & 76 & 0.90 & 0.33 & 0.17 & 7.21 & 0.54 \\
\hline Pakistan & 118 & 0.76 & 0.32 & 0.24 & 6.12 & 0.85 \\
\hline Malaysia & 138 & 5.38 & 0.27 & 0.59 & 7.07 & 0.90 \\
\hline Netherlands & 183 & 11.21 & 0.31 & 1.32 & 6.61 & 0.31 \\
\hline Turkey & 219 & 3.04 & 0.30 & 0.40 & 6.40 & 0.62 \\
\hline Brazil & 329 & 1.76 & 0.30 & 0.31 & 0.77 & 0.31 \\
\hline South Africa & 330 & 7.04 & 0.21 & 0.64 & 10.96 & 1.62 \\
\hline Indonesia & 341 & 1.55 & 0.30 & 0.35 & 10.67 & 1.15 \\
\hline Australia & 377 & 18.47 & 0.32 & 1.82 & 12.07 & 0.55 \\
\hline France & 388 & 6.38 & 0.42 & 1.61 & 0.94 & 0.16 \\
\hline Mexico & 389 & 3.78 & 0.37 & 0.54 & 7.86 & 0.39 \\
\hline Italy & 454 & 7.75 & 0.35 & 1.07 & 5.68 & 0.26 \\
\hline United Kingdom & 530 & 8.80 & 0.43 & 1.45 & 6.20 & 0.19 \\
\hline Germany & 813 & 9.86 & 0.40 & 1.52 & 6.54 & 0.25 \\
\hline India & 1,147 & 1.05 & 0.22 & 0.18 & 17.13 & 1.38 \\
\hline Japan & 1,214 & 9.50 & 0.28 & 1.11 & 5.18 & 0.18 \\
\hline China & 5,101 & 3.91 & 0.14 & 0.33 & 11.76 & 2.30 \\
\hline United States & 5,817 & 19.62 & 0.43 & 3.01 & 7.61 & 0.30 \\
\hline
\end{tabular}

Notes: MT denotes million tons. The consumption intensity numbers include only supplied energy and emissions from household electricity use. 
Table 2: Elasticity of Development, Consumption Energy per capita

\begin{tabular}{|l|ll|ll|}
\hline $\begin{array}{l}\text { Dependent Variable: } \log (\text { Consumption } \\
\text { Energy per capita) }\end{array}$ & OECD & Low Income & OECD & Low Income \\
\hline log(GDP per capita) & $\begin{array}{l}0.773^{* * *} \\
(16.17)\end{array}$ & $\begin{array}{l}0.963^{* * *} \\
(12.42)\end{array}$ & $\begin{array}{l}\text { 4.701*** } \\
(2.835)\end{array}$ & -1.126 \\
& & & $-1.204)$ \\
\hline $\log$ GDP per capita)-squared & & & $-0.192^{* *}$ & $0.126^{* *}$ \\
& & 144 & 292 & 144 \\
\hline Observations & 292 & $1469)$ & $(2.241)$ \\
R-squared & 0.983 & 0.987 & 0.983 & 0.987 \\
\hline
\end{tabular}

Note: $* * * p<0.01, * * p<0.05, * p<0.1 ;$ t-statistics in parentheses. The sample is from 1994 to 2005. The elasticity reported in columns (1) and (2) represent the estimated beta parameter over the period. Regressions include fixed effects.

Table 3: Elasticity of Development, Production Intensity

\begin{tabular}{|c|c|c|c|c|}
\hline $\begin{array}{l}\text { Dependent Variable: log(Production } \\
\text { Intensity) }\end{array}$ & OECD & Low Income & OECD & Low Income \\
\hline $\log ($ GDP per capita) & $\begin{array}{l}-0.911 * * * \\
(-16.48)\end{array}$ & $\begin{array}{l}-0.548 * * * \\
(-9.700)\end{array}$ & $\begin{array}{l}10.41 * * * \\
(5.292)\end{array}$ & $\begin{array}{l}0.209 \\
(0.304)\end{array}$ \\
\hline log(GDP per capita)-squared & & & $\begin{array}{l}-0.551 * * * \\
(-5.757)\end{array}$ & $\begin{array}{l}-0.0456 \\
(-1.103)\end{array}$ \\
\hline Observations & 282 & 156 & 282 & 156 \\
\hline R-squared & 0.982 & 0.986 & 0.984 & 0.986 \\
\hline
\end{tabular}

Note: ${ }^{* *} p<0.01, * * p<0.05, * p<0.1 ;$ t-statistics in parentheses. The sample is from 1994 to 2005. The elasticity reported in columns (1) and (2) represent the estimated gamma parameter over the period. Regressions include fixed effects.

Table 4: Elasticity of Development, Consumption Intensity

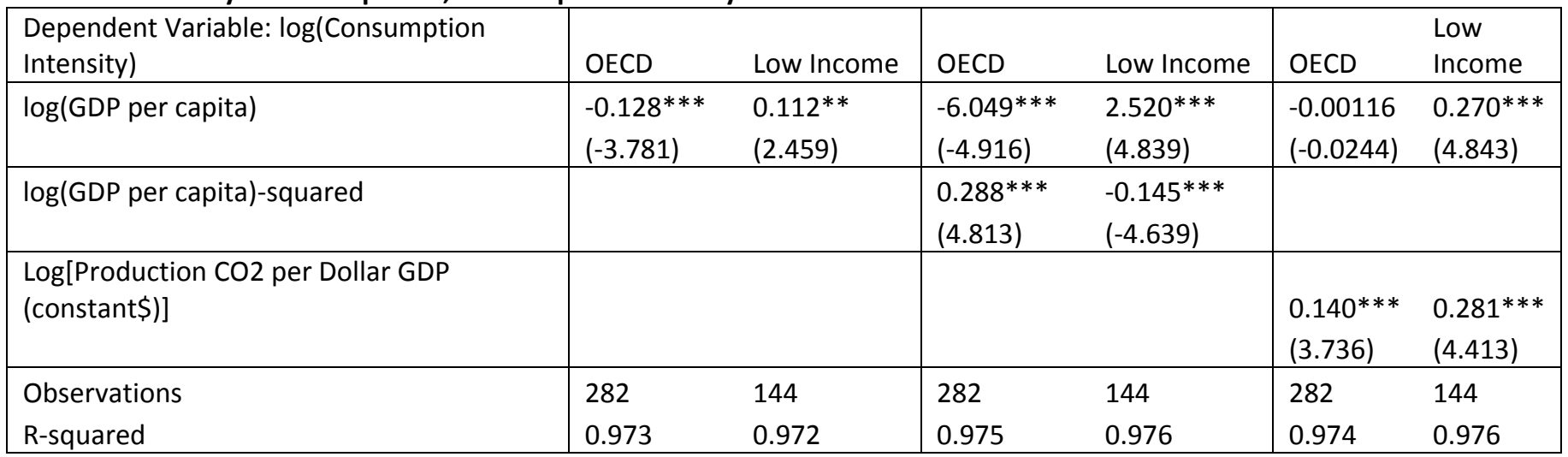

Note: ${ }^{* * *} p<0.01,{ }^{* *} p<0.05, * p<0.1 ; t$-statistics in parentheses. The sample is from 1994 to 2005 . The elasticity reported in columns (1) and (2) represent the estimated gamma parameter over the period. Regressions include fixed effects. 
Table 5: Calculated Elasticities from Quadratic Specification

\begin{tabular}{|c|r|rrr|rr|}
\hline & & & & & & \multicolumn{2}{c|}{$\begin{array}{l}\text { GDP per Capita } \\
\text { (top 10 } \\
\text { emitters) }\end{array}$} \\
\hline \multirow{2}{*}{ Rich } & \multicolumn{1}{|c|}{ Year } & Alpha & Gamma & Beta & GDP per Capita & $30,979.23$ \\
& 2005 & -1.055 & -0.053 & 0.712 & $33,043.74$ & $62,223.61$ \\
\hline \multirow{2}{*}{ Poor } & 2050 & -1.851 & -0.092 & 0.435 & $68,056.99$ & $7,662.07$ \\
& 2005 & -0.586 & -0.079 & 1.129 & $6,205.74$ & $31,537.47$ \\
\hline
\end{tabular}

Note: GDP per capita is specified based on GDP and population projections listed in the Appendix. GDP per capita of the top 10 emitters is calculated based on 2005 emissions. Underlying regressions include fixed effects.

Table 6: Final Parameter Values and Associated Emissions Reductions

\begin{tabular}{|c|c|c|c|c|c|c|c|}
\hline \multirow[b]{2}{*}{ Scenario } & \multirow[b]{2}{*}{ Group } & \multicolumn{3}{|c|}{ Parameters } & \multirow{2}{*}{$\begin{array}{l}\text { Income Group CO2 } \\
\text { Reduction } \\
\text { (percent change } \\
\text { from } 1990 \text { levels) }\end{array}$} & \multirow{2}{*}{$\begin{array}{l}\text { Global CO2 } \\
\text { Reduction } \\
\text { (percent change } \\
\text { from } 1990 \text { levels) }\end{array}$} & \multirow{2}{*}{$\begin{array}{l}\text { Equitable } \\
\text { Reduction for Rich } \\
\text { (percent change } \\
\text { from } 1990 \text { levels) } \\
\end{array}$} \\
\hline & & Alpha & Gamma & Beta & & & \\
\hline \multirow{2}{*}{ 1. BAU } & Rich & -1.453 & -0.073 & 0.573 & -48 & -112 & 251 \\
\hline & Poor & -1.107 & -0.079 & 0.929 & -189 & & \\
\hline \multirow{2}{*}{$\begin{array}{l}\text { 2. Current } \\
\text { Technology } \\
\text { Frontier }\end{array}$} & Rich & -2.081 & -0.509 & -0.314 & 12 & -15 & 132 \\
\hline & Poor & -1.735 & -0.502 & 0.929 & -47 & & \\
\hline \multirow{2}{*}{$\begin{array}{l}\text { 3. Avoiding } \\
\text { Armageddon }\end{array}$} & Rich & -4.058 & -0.993 & -0.314 & 53 & 50 & 53 \\
\hline & Poor & -3.712 & -0.986 & 0.929 & 47 & & \\
\hline
\end{tabular}

Note: A negative reduction implies an increase in emissions. The final column specifies the equitable reduction for the Rich countries, i.e., what sort of reduction would be required by the Rich alone in order to meet the emissions target $(50 \%$ reduction by 2050). This can be contrasted with the value in the Income Group $\mathrm{CO} 2$ reduction column. Scenario I is indicates BAU projections; Scenario II is the current technology frontier; Scenario III is the Avoiding Armageddon scenario.

Table 7: Parameter values before and after oil shock

\begin{tabular}{|l|c|c|}
\hline & Pre-1973 Oil Shock & Post-1973 Oil Shock \\
\hline $\begin{array}{l}\text { Elasticity of CO2 Intensity of } \\
\text { Production }\end{array}$ & -0.084 & -1.137 \\
\hline $\begin{array}{l}\text { Elasticity of Energy Use per } \\
\text { capita }\end{array}$ & 1.246 & 1.162 \\
\hline
\end{tabular}

Note: The values represent a mixed sample: the "pre" period is 1960-1973 and 1965-1973, the "post" period is 1975-1985 and 1975-1990. The sample countries are OECD countries, as well as the top 10 richest OECD countries, judged by GDP per capita, PPP, in 2004. 
Table 8: Sensitivity Analysis on Scenario 3

\begin{tabular}{|c|c|c|c|c|c|c|c|}
\hline \multirow{2}{*}{ Scenario } & \multirow{2}{*}{ Group } & \multicolumn{3}{|c|}{ Parameters } & $\begin{array}{l}\text { Income Group CO2 } \\
\text { Reduction }\end{array}$ & $\begin{array}{l}\text { Global CO2 } \\
\text { Reduction }\end{array}$ & $\begin{array}{l}\text { Equitable Reduction } \\
\text { for Rich }\end{array}$ \\
\hline & & Alpha & Gamma & Beta & 1990 levels) & from 1990 levels) & from 1990 levels) \\
\hline \multirow{2}{*}{$3 a$} & Rich & -5.072 & -1.241 & -0.31 & 63 & 63 & 38 \\
\hline & Poor & -4.726 & -1.234 & 0.929 & 64 & & \\
\hline \multirow{2}{*}{$3 b$} & Rich & -4.058 & -0.993 & -0.392 & 54 & 56 & 42 \\
\hline & Poor & -3.712 & -0.986 & 0.697 & 60 & & \\
\hline
\end{tabular}

Note: Scenario 3 a improves the efficiency parameters -- alpha and gamma -- by 25\% over the value in Scenario 3. Scenario $3 b$ reduces the consumption paramter -- beta -- by 25\% with respect to Scenario 3. 
Appendix Table 1: Sectoral Breakdown of Consumption- and Production-Related Emissions (2005)

\begin{tabular}{|c|c|c|c|c|c|c|c|c|c|}
\hline Country & Residential & $\begin{array}{c}\text { Personal } \\
\text { automobiles }\end{array}$ & $\begin{array}{l}\text { "Consumption- } \\
\text { related" } \\
\text { emissions }\end{array}$ & Commercial & Industrial & Agricultural & $\begin{array}{l}\text { Production } \\
\text { transportation }\end{array}$ & $\begin{array}{l}\text { "Production- } \\
\text { related" } \\
\text { emissions }\end{array}$ & $\begin{array}{c}\text { Total } \\
\text { energy- } \\
\text { related } \\
\text { emissions }\end{array}$ \\
\hline Australia & 71 & 49 & 120 & 55 & 163 & 8 & 21 & 257 & 377 \\
\hline Brazil & 21 & 79 & 100 & 9 & 149 & 16 & 45 & 229 & 329 \\
\hline China & 612 & 126 & 738 & 246 & 3,399 & 201 & 102 & 4,362 & 5,101 \\
\hline France & 78 & 84 & 162 & 39 & 124 & 9 & 44 & 226 & 388 \\
\hline Germany & 201 & 128 & 329 & 105 & 320 & 10 & 22 & 485 & 813 \\
\hline India & 223 & 33 & 256 & 63 & 653 & 160 & 58 & 891 & 1,147 \\
\hline Indonesia & 65 & 37 & 102 & 24 & 171 & 7 & 30 & 239 & 341 \\
\hline Japan & 217 & 125 & 342 & 229 & 547 & 15 & 99 & 873 & 1,214 \\
\hline Mexico & 50 & 93 & 143 & 18 & 182 & 12 & 31 & 246 & 389 \\
\hline Russia & 197 & 73 & 270 & 101 & 870 & 29 & 42 & 1,274 & 1,544 \\
\hline South Africa & 49 & 21 & 70 & 33 & 169 & 9 & 19 & 260 & 330 \\
\hline United Kingdom & 142 & 86 & 228 & 70 & 196 & 4 & 34 & 302 & 530 \\
\hline United States & 1,237 & 1,267 & 2,504 & 1,060 & 1,589 & 51 & 263 & 3,313 & 5,817 \\
\hline
\end{tabular}

Notes: 1) Units are million metric tons of carbon dioxide. 2) Production-related emissions are technically calculated as total emissions minus consumption-related emissions. The sum of Commercial, Industrial, Agricultural, and Production transportation emissions does not sum exactly to the total for production-related emissions due to existence of emissions resulting from energy transformation; sectoral totals are given to illustrate relative sizes only. 3 ) Agricultural emissions include only those related to fossil fuel use. 
Appendix Table 2: Alternative Beta Parameter

\begin{tabular}{|l|rr|}
\hline $\begin{array}{l}\text { Dependent Variable: } \\
\log (\text { Consumption Road km per capita) }\end{array}$ & OECD & OECD \\
\hline log(GDP per capita) & $\begin{array}{rr}0.599 * * * \\
(-6.496)\end{array}$ & $\begin{array}{l}8.619 * \\
(-1.787)\end{array}$ \\
\hline log(GDP per capita)-squared & $\begin{array}{r}-0.392^{*} \\
(-1.663)\end{array}$ \\
\hline Observations & 117 & 117 \\
R-squared & 0.938 & 0.94 \\
\hline
\end{tabular}

Note: ${ }^{* *} p<0.01,{ }^{* *} p<0.05,{ }^{*} p<0.1 ; t$-statistics in parentheses. The dependent variable is consumption road miles traveled between 1990 and 2005 for OECD countries, where data is available. 
Appendix Table 3: Descriptive statistics (selected countries)

\begin{tabular}{|c|c|c|c|c|c|c|c|c|c|c|c|c|c|c|}
\hline \multirow[b]{2}{*}{ Country } & \multicolumn{5}{|c|}{2005} & \multicolumn{5}{|c|}{ 2050: Scenario 1, BAU } & \multicolumn{4}{|c|}{ 2050: Scenario 3, Avoiding Armageddon } \\
\hline & $\begin{array}{l}\text { GDP } \\
\text { per } \\
\text { capita }\end{array}$ & $\begin{array}{l}\text { Total } \\
\text { Emissions }\end{array}$ & $\begin{array}{l}\text { Emissions } \\
\text { per } \\
\text { capita } \\
\text { tCO2 per } \\
\text { capita }\end{array}$ & $\begin{array}{l}\text { Residential } \\
\text { Energy per } \\
\text { capita } \\
\text { toe per } \\
\text { capita }\end{array}$ & $\begin{array}{l}\text { Production } \\
\text { Emissions } \\
\text { Intensity } \\
t C O 2 / \$ 1000\end{array}$ & $\begin{array}{l}\text { GDP } \\
\text { per } \\
\text { capita }\end{array}$ & $\begin{array}{l}\text { Total } \\
\text { Emissions }\end{array}$ & $\begin{array}{l}\text { Emissions } \\
\text { per } \\
\text { capita } \\
\text { tCO2 per } \\
\text { capita }\end{array}$ & $\begin{array}{l}\text { Residential } \\
\text { Energy per } \\
\text { capita } \\
\text { toe per } \\
\text { capita }\end{array}$ & $\begin{array}{l}\text { Production } \\
\text { Emissions } \\
\text { Intensity } \\
t C O 2 / \$ 1000\end{array}$ & $\begin{array}{l}\text { Total } \\
\text { Emissions }\end{array}$ & $\begin{array}{l}\text { Emissions } \\
\text { per } \\
\text { capita } \\
\text { tCO2 per } \\
\text { capita }\end{array}$ & $\begin{array}{l}\text { Residential } \\
\text { Energy per } \\
\text { capita } \\
\text { toe per } \\
\text { capita }\end{array}$ & $\begin{array}{l}\text { Production } \\
\text { Emissions } \\
\text { Intensity } \\
t C O 2 / \$ 1000\end{array}$ \\
\hline Turkey & 7,786 & 219 & 3.09 & 0.40 & 0.62 & 31,094 & 531 & 5.43 & 1.45 & 0.16 & 131 & 1.34 & 1.45 & 0.01 \\
\hline Saudi Arabia & 21,220 & 320 & 13.19 & 1.59 & 0.88 & 64,463 & 798 & 14.58 & 3.15 & 0.20 & 135 & 2.46 & 1.46 & 0.02 \\
\hline Brazil & 8,474 & 329 & 1.86 & 0.31 & 0.31 & 33,842 & 768 & 3.29 & 1.12 & 0.08 & 192 & 0.82 & 1.12 & 0.00 \\
\hline South Africa & 8,478 & 330 & 7.58 & 0.64 & 1.62 & 33,857 & 471 & 11.71 & 2.33 & 0.41 & 100 & 2.48 & 2.33 & 0.03 \\
\hline Indonesia & 3,209 & 341 & 1.56 & 0.35 & 1.15 & 18,747 & 1,004 & 3.42 & 1.83 & 0.20 & 203 & 0.69 & 1.83 & 0.01 \\
\hline Spain & 27,180 & 342 & 8.46 & 1.17 & 0.30 & 53,116 & 331 & 8.86 & 1.77 & 0.12 & 109 & 2.91 & 1.12 & 0.03 \\
\hline Australia & 34,106 & 377 & 19.11 & 1.82 & 0.55 & 66,651 & 489 & 19.13 & 2.75 & 0.22 & 155 & 6.08 & 1.73 & 0.06 \\
\hline France & 30,591 & 388 & 6.50 & 1.61 & 0.16 & 59,782 & 444 & 6.91 & 2.43 & 0.06 & 147 & 2.29 & 1.53 & 0.02 \\
\hline Mexico & 11,387 & 389 & 3.80 & 0.54 & 0.39 & 40,772 & 963 & 6.87 & 1.80 & 0.11 & 278 & 1.98 & 1.80 & 0.01 \\
\hline Italy & 27,750 & 454 & 8.09 & 1.07 & 0.26 & 54,229 & 370 & 8.24 & 1.62 & 0.11 & 119 & 2.65 & 1.02 & 0.03 \\
\hline United Kingdom & 31,371 & 530 & 8.92 & 1.45 & 0.19 & 61,306 & 632 & 9.55 & 2.20 & 0.08 & 211 & 3.19 & 1.39 & 0.02 \\
\hline Canada & 34,972 & 549 & 17.41 & 2.26 & 0.47 & 68,342 & 673 & 17.22 & 3.41 & 0.19 & 212 & 5.42 & 2.15 & 0.05 \\
\hline Germany & 30,445 & 813 & 9.92 & 1.52 & 0.25 & 59,495 & 828 & 10.47 & 2.30 & 0.10 & 273 & 3.45 & 1.45 & 0.03 \\
\hline India & 2,222 & 1,147 & 1.08 & 0.18 & 1.38 & 19,962 & 4,008 & 2.62 & 1.39 & 0.16 & 584 & 0.38 & 1.39 & 0.00 \\
\hline Japan & 30,290 & 1,214 & 9.70 & 1.11 & 0.18 & 52,976 & 1,038 & 9.46 & 1.57 & 0.08 & 388 & 3.54 & 1.07 & 0.03 \\
\hline Russia & 11,858 & 1,544 & 10.99 & 1.48 & 3.64 & 42,459 & 1,555 & 15.33 & 4.90 & 1.04 & 321 & 3.16 & 4.90 & 0.08 \\
\hline China & 4,088 & 5,101 & 3.96 & 0.33 & 2.30 & 23,881 & 8,796 & 6.30 & 1.73 & 0.41 & 1,266 & 0.91 & 1.73 & 0.01 \\
\hline United States & 41,813 & 5,817 & 19.69 & 3.01 & 0.30 & 81,712 & 8,616 & 21.08 & 4.55 & 0.12 & 2,874 & 7.03 & 2.87 & 0.03 \\
\hline
\end{tabular}

Note: Residential energy is defined as the sum of total household energy use and household road travel. Countries sorted by total emissions in 2005. 


\begin{tabular}{|c|c|c|c|c|c|c|c|c|c|c|c|c|}
\hline & AUS & CAN & DEU & FIN & FRA & GBR & USA & BRA & CHN & IDN & IND & MEX \\
\hline \multicolumn{13}{|l|}{ Beta Regression Results } \\
\hline Log[GDP per capita, PPP] & $\begin{array}{l}0.314 * * * \\
(0.0622)\end{array}$ & $\begin{array}{l}0.328 * * * \\
(0.0258)\end{array}$ & $\begin{array}{l}0.128 \\
(0.0890)\end{array}$ & $\begin{array}{l}0.355 * * * \\
(0.0358)\end{array}$ & $\begin{array}{l}0.767 * * * \\
(0.0873)\end{array}$ & $\begin{array}{l}0.133 \\
(0.102)\end{array}$ & $\begin{array}{l}0.804 * * * \\
(0.0377)\end{array}$ & $\begin{array}{l}1.886 * * * \\
(0.273)\end{array}$ & $\begin{array}{l}1.011 * * * \\
(0.0235)\end{array}$ & $\begin{array}{l}2.132 * * * \\
(0.317)\end{array}$ & $\begin{array}{l}0.288 * * * \\
(0.0822)\end{array}$ & $\begin{array}{l}1.873 * * * \\
(0.136)\end{array}$ \\
\hline Constant & $\begin{array}{l}-10.17^{* * *} \\
(0.639)\end{array}$ & $\begin{array}{l}-10.04 * * * \\
(0.266)\end{array}$ & $\begin{array}{l}-8.559 * * * \\
(0.912)\end{array}$ & $\begin{array}{l}-10.65^{* * *} \\
(0.362)\end{array}$ & $\begin{array}{l}-15.19 * * * \\
(0.891)\end{array}$ & $\begin{array}{l}-8.683^{* * *} \\
(1.037)\end{array}$ & $\begin{array}{l}-14.83^{* * *} \\
(0.395)\end{array}$ & $\begin{array}{l}-25.49 * * * \\
(2.444)\end{array}$ & $\begin{array}{l}-18.31^{* * *} \\
(0.181)\end{array}$ & $\begin{array}{l}-26.75^{* * *} \\
(2.502)\end{array}$ & $\begin{array}{l}-13.17^{* * *} \\
(0.604)\end{array}$ & $\begin{array}{l}-25.50 * * * \\
(1.257)\end{array}$ \\
\hline R-squared & 0.646 & 0.920 & 0.128 & 0.876 & 0.847 & 0.108 & 0.970 & 0.773 & 0.992 & 0.764 & 0.468 & 0.931 \\
\hline \multicolumn{13}{|l|}{ Alpha Regression Results } \\
\hline Log[GDP per capita, PPP] & $\begin{array}{l}-0.404 * * * \\
(0.0548)\end{array}$ & $\begin{array}{l}-0.445 * * * \\
(0.0467)\end{array}$ & $\begin{array}{l}-2.081^{* * *} \\
(0.150)\end{array}$ & $\begin{array}{l}-0.614 * * * \\
(0.184)\end{array}$ & $\begin{array}{l}-1.244 * * * \\
(0.110)\end{array}$ & $\begin{array}{l}-1.275^{* * *} \\
(0.0793)\end{array}$ & $\begin{array}{l}-1.137^{* * *} \\
(0.0556)\end{array}$ & $\begin{array}{l}1.126 * * * \\
(0.260)\end{array}$ & $\begin{array}{l}-0.575^{* * *} \\
(0.0589)\end{array}$ & $\begin{array}{l}0.382 \\
(0.234)\end{array}$ & $\begin{array}{l}-0.455^{* * *} \\
(-0.0407)\end{array}$ & $\begin{array}{l}-1.252 * * * \\
(0.0903)\end{array}$ \\
\hline Constant & $\begin{array}{l}-17.10 * * * \\
(0.562)\end{array}$ & $\begin{array}{l}-16.80 * * * \\
(0.481)\end{array}$ & $\begin{array}{l}-0.646 \\
(1.533)\end{array}$ & $\begin{array}{l}-15.56 * * * \\
(1.861)\end{array}$ & $\begin{array}{l}-9.717^{* * *} \\
(1.119)\end{array}$ & $\begin{array}{l}-9.224 * * * \\
(0.807)\end{array}$ & $\begin{array}{l}-9.796 * * * \\
(0.584)\end{array}$ & $\begin{array}{l}-32.01 * * * \\
(2.330)\end{array}$ & $\begin{array}{l}-15.29 * * * \\
(0.453)\end{array}$ & $\begin{array}{l}-23.73 * * * \\
(1.848)\end{array}$ & $\begin{array}{l}-16.86 * * * \\
(-0.299)\end{array}$ & $\begin{array}{l}-9.994 * * * \\
(0.833)\end{array}$ \\
\hline $\begin{array}{l}\text { R-squared } \\
\text { Gamma Regression } \\
\text { Results }\end{array}$ & 0.795 & 0.867 & 0.932 & 0.443 & 0.902 & 0.949 & 0.968 & 0.572 & 0.872 & 0.161 & 0.899 & 0.932 \\
\hline Log[GDP per capita, PPP] & $\begin{array}{l}0.265 * * * \\
(0.0410)\end{array}$ & $\begin{array}{l}0.203 * * * \\
(0.0502)\end{array}$ & $\begin{array}{l}-0.509 * * * \\
(0.0518)\end{array}$ & $\begin{array}{l}0.0562 \\
(0.119)\end{array}$ & $\begin{array}{l}-0.0546 \\
(0.0669)\end{array}$ & $\begin{array}{l}-0.330 * * * \\
(0.0990)\end{array}$ & $\begin{array}{l}-0.140 * * * \\
(0.0251)\end{array}$ & $\begin{array}{l}0.671 * * * \\
(0.135)\end{array}$ & $\begin{array}{l}0.0626 * * * \\
(0.0174)\end{array}$ & $\begin{array}{l}0.332 * * \\
(0.126)\end{array}$ & $\begin{array}{l}0.968 * * * \\
(0.0921)\end{array}$ & $\begin{array}{l}0.0121 \\
(0.0420)\end{array}$ \\
\hline Constant & $\begin{array}{l}-8.049 * * * \\
(0.421)\end{array}$ & $\begin{array}{l}-7.939 * * * \\
(0.517)\end{array}$ & $\begin{array}{l}-0.347 \\
(0.531)\end{array}$ & $\begin{array}{l}-6.240 * * * \\
(1.204)\end{array}$ & $\begin{array}{l}-5.488 * * * \\
(0.683)\end{array}$ & $\begin{array}{l}-2.197 * * \\
(1.007)\end{array}$ & $\begin{array}{l}-4.068 * * * \\
(0.264)\end{array}$ & $\begin{array}{l}-12.16^{* * *} \\
(1.208)\end{array}$ & $\begin{array}{l}-5.574 * * * \\
(0.134)\end{array}$ & $\begin{array}{l}-8.094 * * * \\
(0.992)\end{array}$ & $\begin{array}{l}-12.01^{* * *} \\
(0.677)\end{array}$ & $\begin{array}{l}-5.775 * * * \\
(0.388)\end{array}$ \\
\hline Observations & 16 & 16 & 16 & 16 & 16 & 16 & 16 & 16 & 16 & 16 & 16 & 16 \\
\hline R-squared & 0.749 & 0.537 & 0.873 & 0.016 & 0.046 & 0.442 & 0.689 & 0.639 & 0.481 & 0.333 & 0.888 & 0.006 \\
\hline
\end{tabular}

Note: Standard errors in parentheses; ${ }^{* * *} p<0.01,{ }^{* *} p<0.05,{ }^{*} p<0.1$ 
Appendix Table 5: Emission-Level Country List

\begin{tabular}{|c|c|c|c|c|c|c|}
\hline \multicolumn{2}{|c|}{ Developed } & \multicolumn{5}{|c|}{ Developing } \\
\hline Netherlands Antilles & Iceland & Angola & Dominican Republic & Kenya & Pakistan & Tanzania \\
\hline United Arab Emirates & Israel & Albania & Algeria & Kyrgyz Republic & Panama & Ukraine \\
\hline Australia & Italy & Argentina & Ecuador & Cambodia & Peru & Uruguay \\
\hline Austria & Japan & Armenia & Egypt, Arab Rep. & Lebanon & Philippines & Uzbekistan \\
\hline Belgium & Korea, Rep. & Azerbaijan & Eritrea & Libya & Poland & Venezuela \\
\hline Bahrain & Kuwait & Benin & Ethiopia & Sri Lanka & Korea, Dem. Rep. & Vietnam \\
\hline Brunei Darussalam & Luxembourg & Bangladesh & Gabon & Lithuania & Paraguay & Yemen, Rep. \\
\hline Canada & Malta & Bulgaria & Georgia & Latvia & Romania & South Africa \\
\hline Switzerland & Netherlands & Bosnia and Herzegovina & Ghana & Morocco & Russia & Congo, Dem. Rep. \\
\hline Cyprus & Norway & Belarus & Guatemala & Moldova & Sudan & Zambia \\
\hline Czech Republic & New Zealand & Bolivia & Honduras & Mexico & Senegal & Zimbabwe \\
\hline Germany & Portugal & Brazil & Croatia & Macedonia, FYR & El Salvador & \\
\hline Denmark & Qatar & Botswana & Haiti & Myanmar & Serbia and Montenegro & \\
\hline Spain & Saudi Arabia & Chile & Hungary & Mongolia & Slovak Republic & \\
\hline Estonia & Singapore & China & Indonesia & Mozambique & Syrian Arab Republic & \\
\hline Finland & Slovenia & Cote d'Ivoire & India & Malaysia & Togo & \\
\hline France & Sweden & Cameroon & Iran, Islamic Rep. & Namibia & Thailand & \\
\hline United Kingdom & Trinidad and Tobago & Congo, Rep. & Iraq & Nigeria & Tajikistan & \\
\hline Greece & United States & Colombia & Jamaica & Nicaragua & Turkmenistan & \\
\hline Hong Kong & & Costa Rica & Jordan & Nepal & Tunisia & \\
\hline Ireland & & Cuba & Kazakhstan & Oman & Turkey & \\
\hline
\end{tabular}


Appendix Table 6: Countries Used in the Regression

Analysis

\begin{tabular}{|ll|l|}
\hline \multicolumn{2}{|c|}{ OECD } & Developing \\
\hline Australia & Ireland & Argentina \\
Austria & Iceland & Brazil \\
Belgium & Italy & China \\
Canada & Japan & Indonesia \\
Switzerland & Korea, Rep. & India \\
Czech Republic & Luxembourg & Mexico \\
Germany & Netherlands & Malaysia \\
Denmark & Norway & Poland \\
Spain & New Zealand & Thailand \\
Finland & Portugal & Turkey \\
France & Sweden & Venezuela \\
United Kingdom & United States & South Africa \\
Greece & & \\
\hline
\end{tabular}




\section{References}

Bhagwati, Jagdish, 2006, “A global warming fund could succeed where Kyoto failed,” Financial Times, Aug 16, 2006.

Birdsall, Nancy and Arvind Subramanian, 2007, "From World Bank to Development Cooperative,” Center for Global Development, available at: http://www.cgdev.org/content/publications/detail/14625

Ghosh, Arunabha, 2009, “Competing needs: clean coal is key,” (http://www.livemint.com/2009/04/27201218/Business-At-Oxford-Competing.html?h=B)

Frankel, Jeffrey, 2009, “An Elaborated Global Climate Policy Architecture: Specific Formulas and Emission Targets for All Countries in All Decades,” NBER Working Paper 14876, forthcoming in Post-Kyoto International Climate Policy, edited by Joe Aldy and Rob Stavins, Cambridge University Press, 2009.

Hufbauer, Gary Clyde, Steve Charnovitz, and Jisun Kim,2009, Global Warming and the World Trading System. Washington: Peterson Institute for International Economics.

Jacoby, Henry, D. Mustafa H. Babiker, Sergey Paltsev and John M. Reilly, 2008, "Sharing the Burden of GHG Reductions,” The Harvard Project on International Climate Change.

Joshi, Vijay and Urjit Patel, 2009, “India and a Carbon Deal,” Vol. XLIV No. 31, pp. 71-77, Economic and Political Weekly,

Mattoo, Aaditya and Arvind Subramanian, 2009, "From Doha to the Next Bretton Woods: A New Multilateral Trade Agenda.” Foreign Affairs 88(1) ( January/February): 15-26.

Planning Commission of the Government of India, 2006, Integrated Energy Policy.

Sen, Amartya, 1999, Development as Freedom, Oxford University Press.

Stern, Nicholas Herbert, 2007, The Economics of Global Climate Change: The Stern Review. Cambridge UK: Cambridge University Press.

Stern, Nicholas Herbert, 2009, “Transatlantic Perspective on Climate Change and Trade Policy.” Keynote address, Peterson Institute for International Economics, March 4.

UNDP, 2007/2008, Human Development Report, "Fighting climate change: Human solidarity in a divided world,” New York.

World Bank, 2010, World Development Report, “Development and Climate Change,” World Bank, Washington D.C. 
Figure 1: Carbon Intensity of Production (Selected Major Emitters), 1960-2005

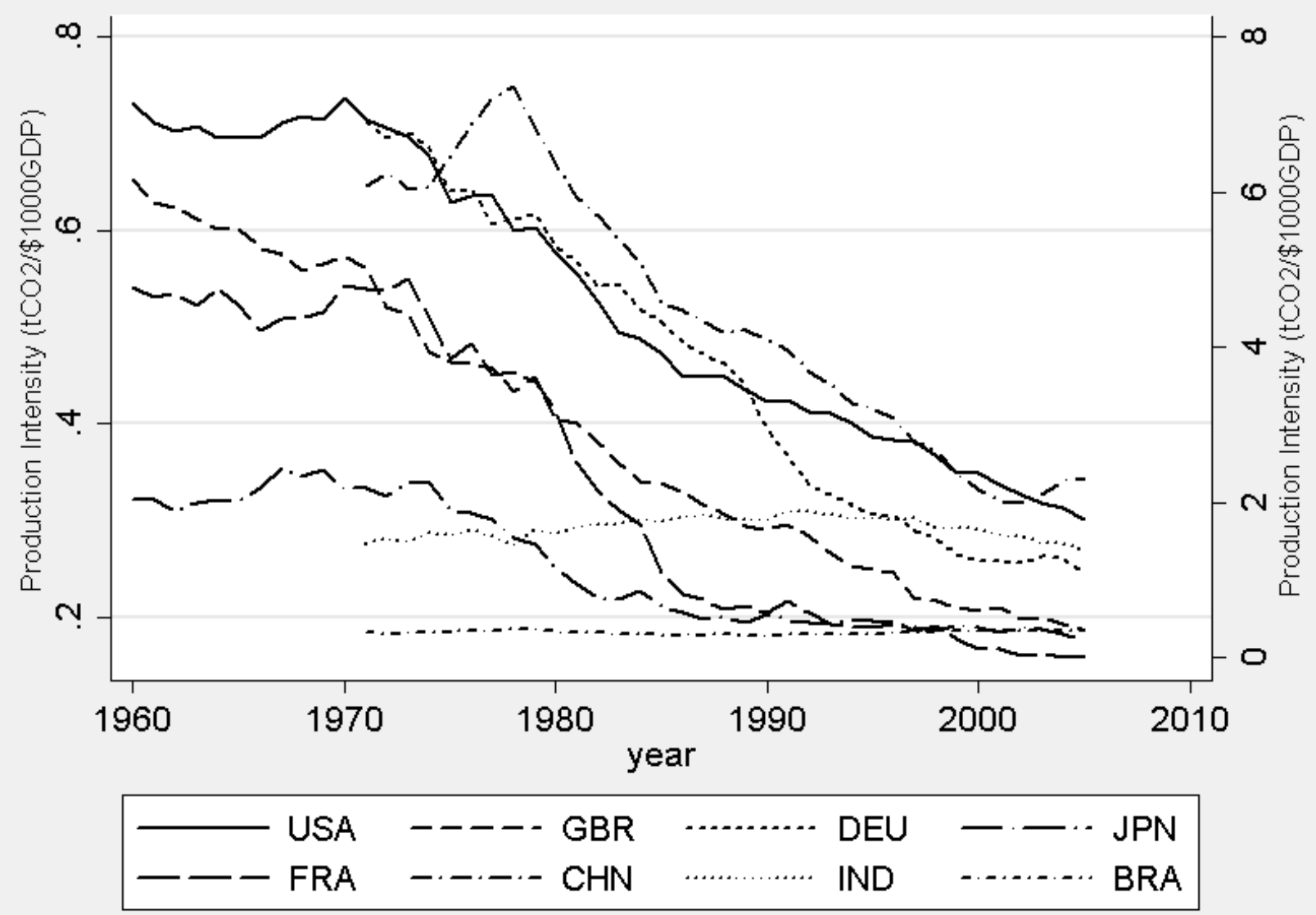

Note: Developed countries (5) appear on the left axis; developing countries (3) appear on the right axis. 
Figure 2. Carbon Intensity of Energy Use (Selected Major Emitters), 1960-2005

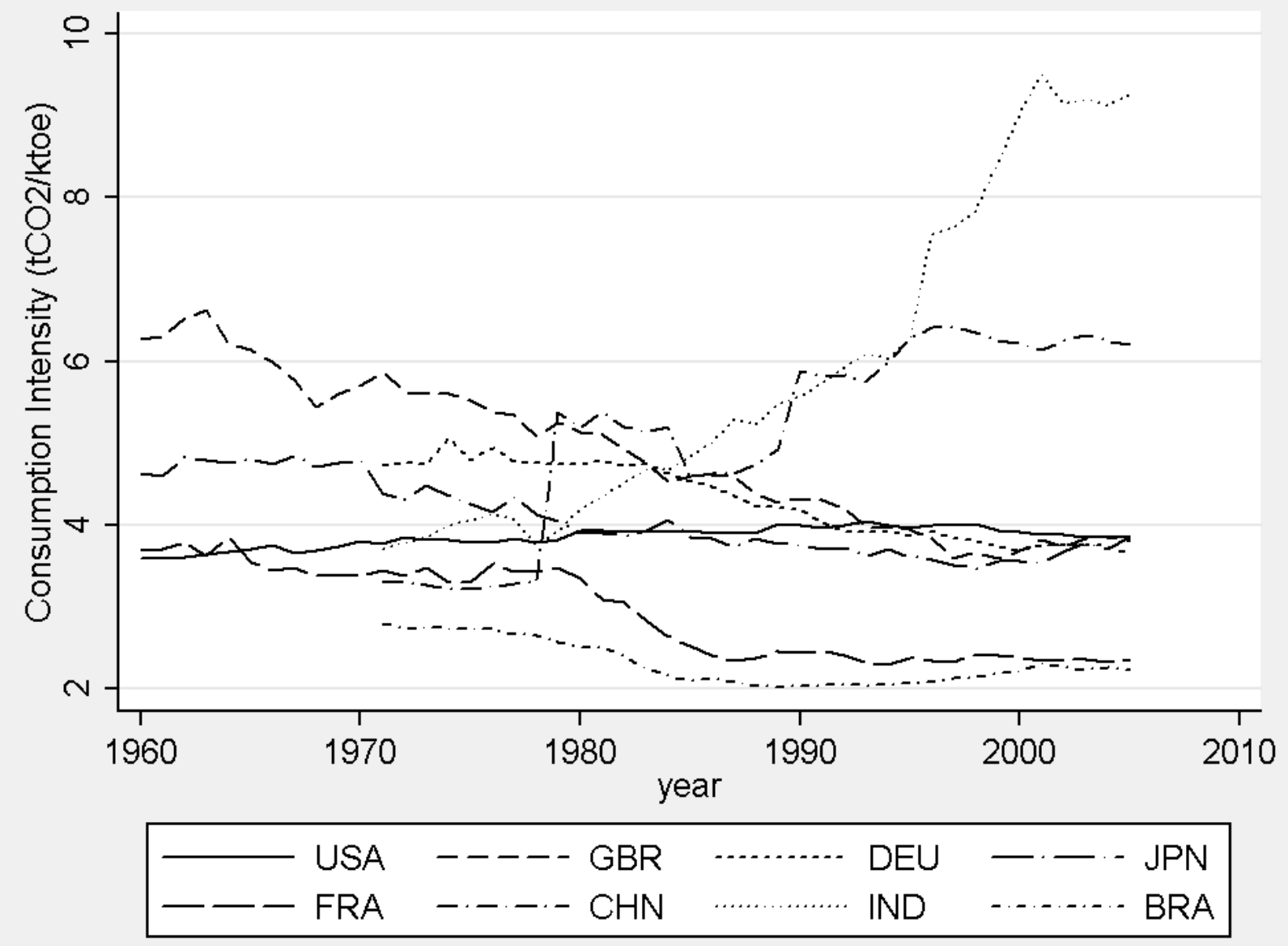


Figure 3. Energy Use per capita (Selected Major Emitters), 1960-2005

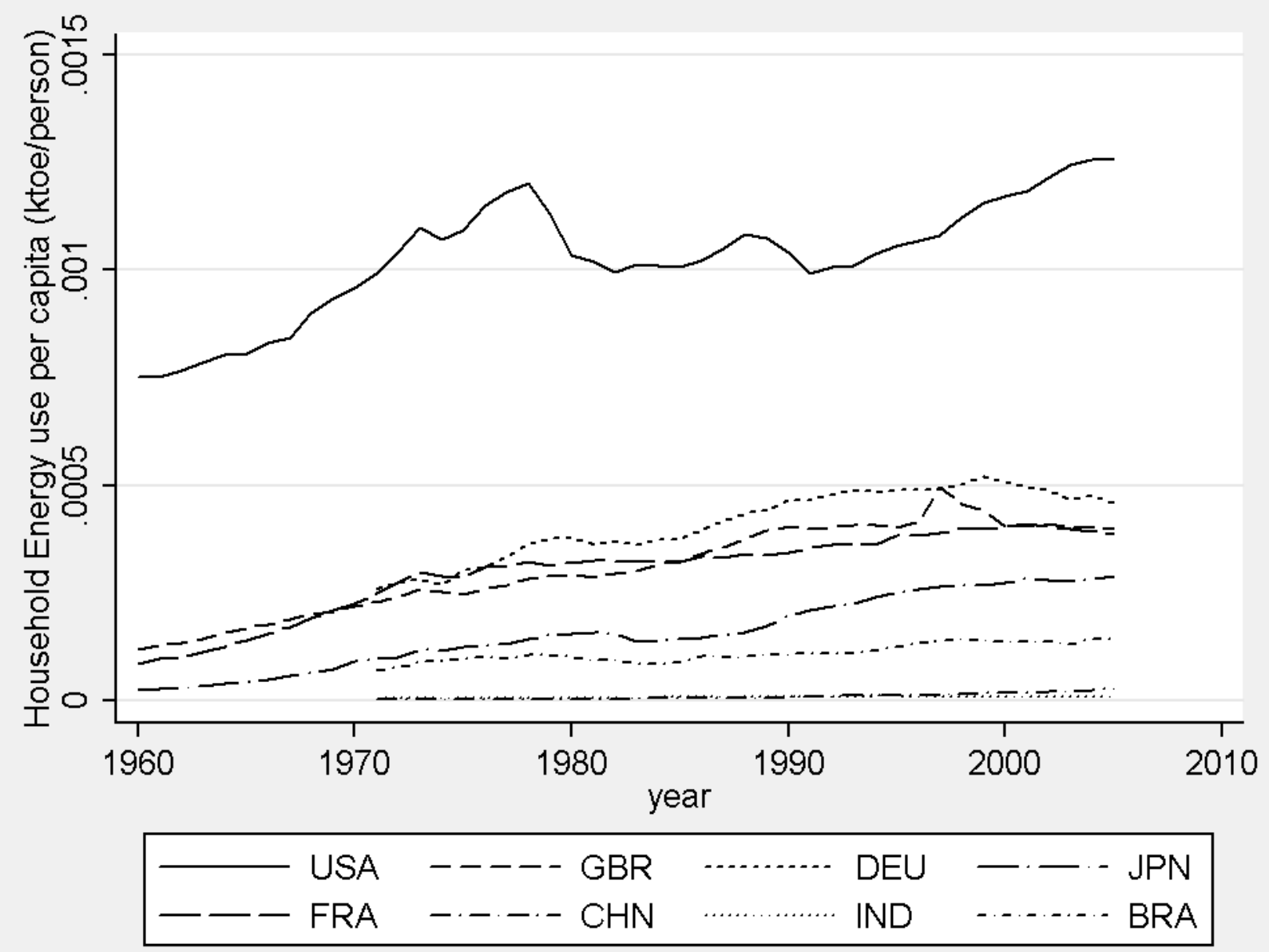


Appendix Figure 1: Energy Use and Carbon Intensity of Consumption Disaggregated by Sectors (Selected Developing Countries), 1960-2005
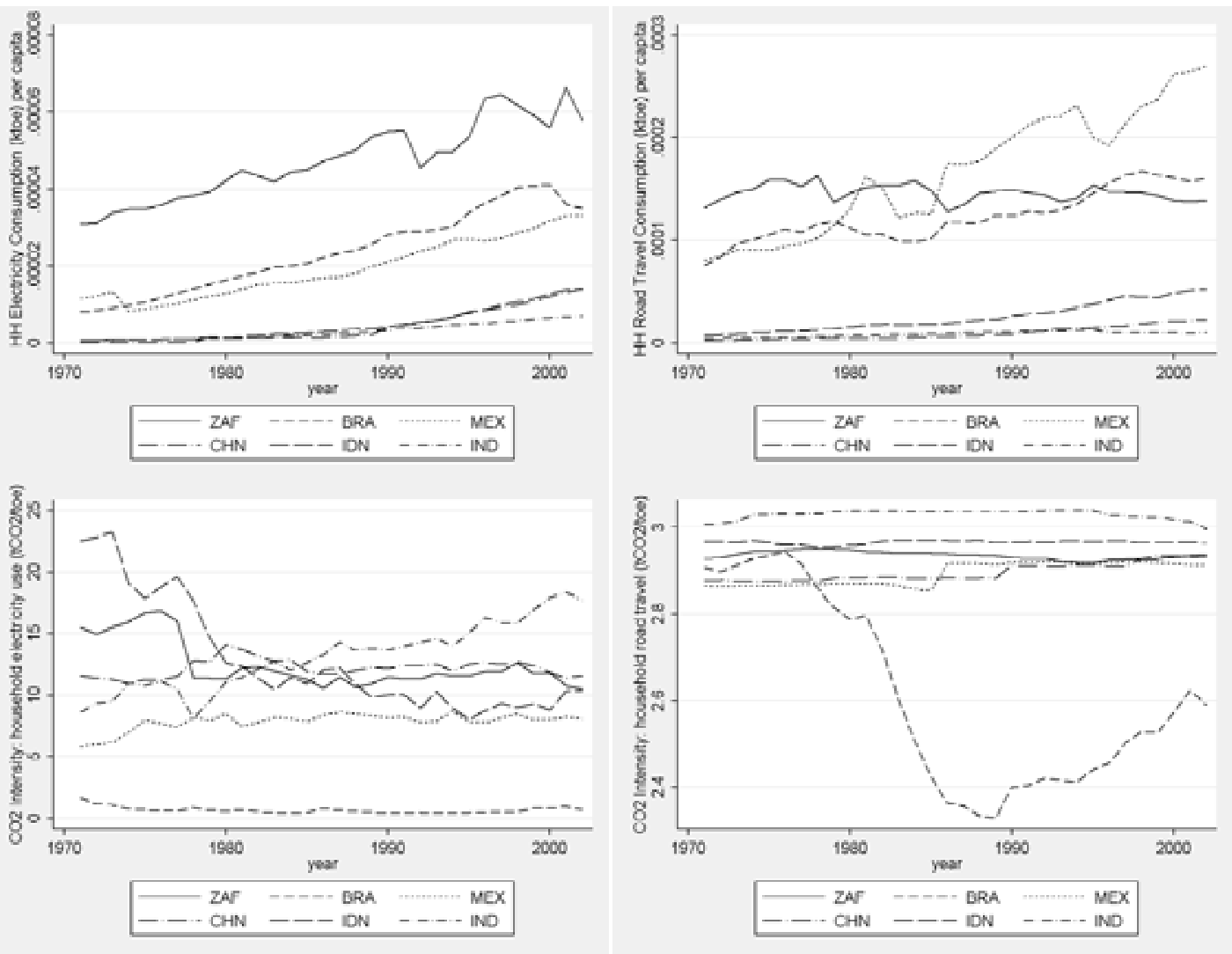
Appendix Figure 2: Energy Use and Carbon Intensity of Consumption Disaggregated by Sectors (Selected Developed Countries), 1960-2005
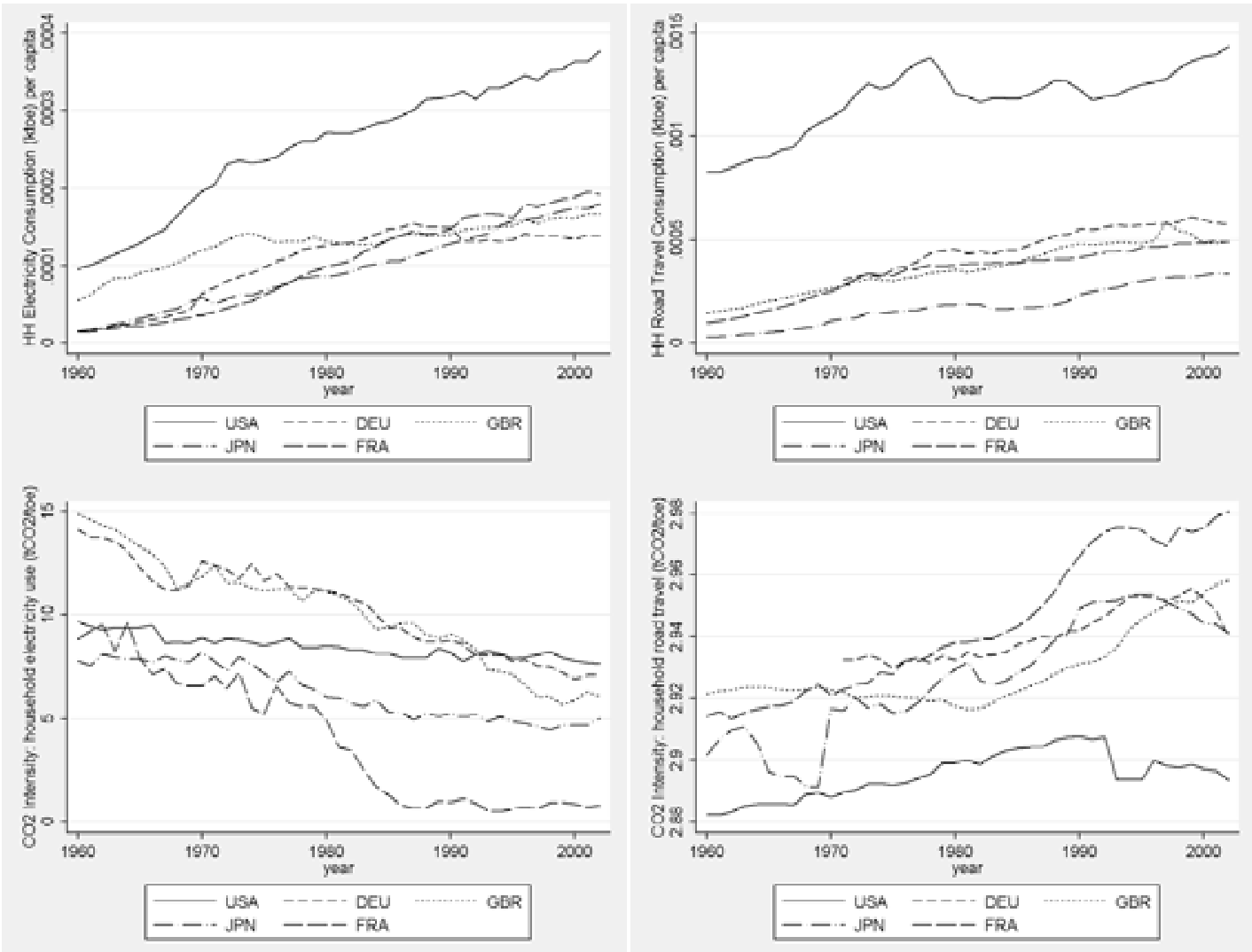